\title{
Deep-water Photinae (Gastropoda: Nassariidae) from eastern Africa, with descriptions of five new species
}

\author{
Koen FRAUSSEN ${ }^{1}$, Lee Ann GALINDO ${ }^{2} \&$ José ROSADO $^{3}$ \\ 1,2 Research Associate Institute of Systematics, Evolution, Biodiversity (ISYEB), Muséum national \\ d'histoire naturelle (MNHN), CNRS, SU, EPHE, UA, CP 51, Rue Cuvier 57, 75005 Paris, France. \\ ${ }^{1}$ Leuvensestraat 25, 3200 Aarschot, Belgium. \\ ${ }^{3}$ Avenida Friedrich Engels 373-1², 1101 Maputo, Mozambique. \\ ${ }^{1}$ Corresponding author: koen.fraussen@skynet.be \\ ${ }^{2}$ Email: akamaikai@gmail.com \\ ${ }^{3}$ Email: joserosadoi@hotmail.com \\ ${ }^{1}$ urn:Isid:zoobank.org:author:5F9EFCF2-5BCF-486E-8D3E-088D85C45882 \\ ${ }^{2}$ urn:lsid:zoobank.org:author:B84DC387-F1A5-4FE4-80F2-5C93E41CEC15 \\ ${ }^{3}$ urn:lsid:zoobank.org:author:0415DDDF-2BC1-40CC-9DF6-06146A31C7AB
}

\begin{abstract}
Deep-water species from the western Indian Ocean off the East African coast and Madagascar, belonging to the subfamily Photinae, are discussed and compared with species from the West Pacific. Phos elegantissimus Hayashi \& Habe, 1965, P. hirasei Sowerby, 1913 and P. laevis Kuroda \& Habe in Habe, 1961 are recorded from Mozambique and/or from Madagascar, hereby extending their known range considerably into the western Indian Ocean. The East African specimens formerly assigned to Phos roseatus Hinds, 1844 are found to differ from this West Pacific species. In total, five species are described as new: Phos ganii sp. nov., P. geminus sp. nov., P. ladoboides sp. nov., P. pulchritudus sp. nov. and $P$. testaceus sp. nov.
\end{abstract}

Keywords. Nassariidae, Photinae, Indian Ocean, eastern Africa, deep-water.

Fraussen K., Galindo L.A. \& Rosado J. 2020. Deep-water Photinae (Gastropoda: Nassariidae) from eastern Africa, with descriptions of five new species. European Journal of Taxonomy 720: 144-169.

https://doi.org/10.5852/ejt.2020.720.1123

\section{Introduction}

The East African coasts of Mozambique and Madagascar are blessed with a unique fauna, largely underestimated in the past. Besides the large number of endemic species, this fauna overlaps with the colder water fauna of South Africa and the equatorial fauna of East Africa. Uprising currents from the deep-water faunas are present, relative to the rich Mozambique Channel Abyssal, from the Natal Basin (in the south) and the Somalian Basin (in the north). Some years ago the fauna offshore of East Africa and Madagascar also became investigated more intensively, leading to a large number of discoveries, among them hitherto unknown molluscan taxa. The material studied in the present paper originates partly from deep-water cruises conducted by MNHN and the Institut de Recherche pour le Développement (IRD) as part of the 'Tropical Deep-Sea Benthos' programme and/or by MNHN and 
Pro-Natura International (PNI) as part of the 'Our Planet Reviewed' programme, and partly from a dedicated team of keen collectors diving and dredging along the coasts of Mozambique, Madagascar and South Africa.

Several specific deep-water cruises were involved. REVES-2 (1980) took place at the Seychelles. The MD32 cruise (1982) on board R/V Marion-Dufresne (Principal Investigator Alain Guille) collected off Réunion and Campagne CREVETTIERE $(1971,1974)$ off Madagascar. The MIRIKY (2009), MAINBAZA (2009) and ATIMO VATAE (2010) cruises (Principal Investigator: Philippe Bouchet), respectively on board R/V Vizconde de Eza, F/V Miriky and R/V Antéa, were part of a cluster of Mozambique-Madagascar 2009-2010 expeditions in partnership with Institut d'Halieutique et des Sciences Marines, University of Toliara (IH.SM), the Madagascar bureau of the Wildlife Conservation Society (WCS) and Instituto Español de Oceanografia (IOE), with funding from the Total Foundation, Prince Albert II of Monaco Foundation, and the Stavros Niarchos Foundation (https://doi.org/10.17600/10110040). The INHACA 2011 expedition with Universidade Eduardo Mondlane through Jose Rosado collected in Mozambique and the BIOMAGLO cruise in the Mozambique Channel took place on board R/V Antéa (PIs Laure Corbari, Sarah Samadi) (https://doi.org/10.17600/17004000).

Part of the deep-water Photinae thus collected fall within the subspecific variability of already known West Pacific species. As a result, the ranges of Phos elegantissimus Hayashi \& Habe, 1965, P. hirasei Sowerby, 1913 and $P$. laevis Kuroda \& Habe, 1961 are confirmed to include the western Indian Ocean. The shells commonly assigned to $P$. roseatus Hinds, 1844 are known to be conchologically slightly different from this West Pacific species and molecular evidence (Fraussen \& Galindo in prep.) confirms that those East African specimens are not conspecific with P. roseatus from the West Pacific. Shells that look very similar in sculpture and pattern to Phos idyllium (Fraussen \& Poppe, 2005) are found to be conchologically different from this West Pacific species. As a result, five deep-water species of Phos are described as new to science and added to the fauna of the western Indian Ocean: Phos geminus sp. nov., P. ladoboides sp. nov., P. testaceus sp. nov., $P$. pulchritudus sp. nov. and $P$. ganii sp. nov. In addition, one more species is listed and figured as Phos sp.

\section{Material and methods}

Unless otherwise indicated, material from the French expeditions is deposited in the collections of the Muséum national d'histoire naturelle (MNHN). Apart from types, no individual catalogue numbers have been allocated, but lots are unambiguously designated and retrievable by the combination of expedition acronym and station number.

All species from Africa were compared to large collections of Photinae from the Central Pacific Ocean from at least four private and one public collection (see abbreviations).

Bathymetric ranges are provided for each species, including live-collected specimens only (when applicable), and they are reported as inner values of the shallowest and deepest stations as explained by Bouchet et al. (2008).

The method of Verduin (1977) was employed to count the number of protoconch whorls.

\section{Abbreviations}

$$
\begin{array}{ll}
\mathrm{AS} & =\text { collection of Alan Seccombe, South Africa } \\
\mathrm{JR} & =\text { collection of José Rosado, Mozambique } \\
\mathrm{KF} & =\text { collection of Koen Fraussen, Belgium } \\
\mathrm{MNHN} & =\text { Muséum national d'histoire naturelle, Paris, France } \\
\mathrm{SG} & =\text { collection of Sandro Gori, Italy }
\end{array}
$$




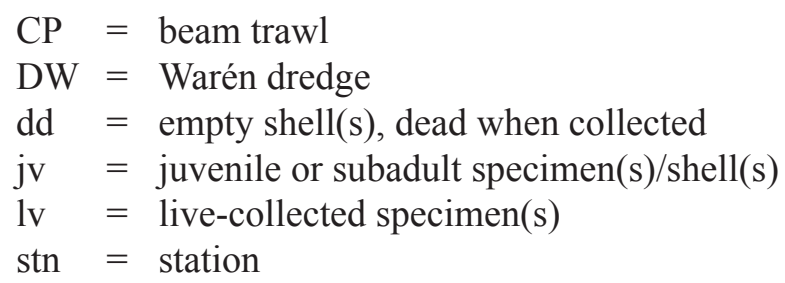

\section{Results}

Phylum Mollusca Linnaeus, 1758

Class Gastropoda Cuvier, 1795

Subclass Caenogastropoda Cox, 1960

Order Neogastropoda Wenz, 1938

Superfamily Buccinoidea Rafinesque, 1815

Family Nassariidae Iredale, 1916 (1835)

Subfamily Photinae Gray, 1857

Genus Phos Montfort, 1810

Phos Montfort, 1810: 484-486.

\section{Type species}

Murex senticosus Linnaeus, 1758, by original designation (Tropical Indo-West Pacific).

\section{Remarks}

The Photinae were recently the subject of a profound taxonomic revision (Galindo et al. 2016). Molecular data prove that all species belonging to Phos Montfort, 1810 represent a monophyletic group occuring exclusively in the Indo-West Pacific, distinct from the Carribean Antillophos Woodring, 1928 (see Galindo et al. 2016: 343, fig. 1, 345, fig. 2, 348, fig. 3). It is typical that genera within Nassariidae are geographically restricted clades, while the biogeographic range of genera is usually broader in Buccinidae. The generic separation within Photinae based on sculpture and protoconch morphology, as discussed by Fraussen \& Poppe (2005: 76-77, 81-82), no longer holds. As a result, Phos senticosus, with a smooth protoconch, is congeneric with other Indo-West Pacific species that have a characteristically sculptured protoconch and that were formerly placed in Antillophos. For a discussion about the taxonomic positions of Phos and Antillophos within Nassariidae, we refer to Galindo et al. (2016).

Phos elegantissimus Hayashi \& Habe, 1965

Fig. $1 \mathrm{~A}-\mathrm{C}$

Phos elegantissimum Hayashi \& Habe, 1965: 11, 14, pl. 1, fig. 4.

Antillophos elegantissimum - Kilburn, Marais \& Fraussen 2010: 25.

\section{Type locality}

Japan, Mie Prefecture, mouth of Ise Bay, depth 100-120 m.

\section{Material examined}

MOZAMBIQUE • 3 lv; North Quissico, in traps; depth 95-135 m; J. Rosado leg.; JR (Fig. 1A-B) • 1 dd; off Sofala Bank, ex-pisces; depth 120-140 m; J. Rosado leg.; JR (Fig. 1C). 


\section{Distribution}

This species is known from the West Pacific, from southern Japan in the north to the Philippines in the south, and has also been recorded from South Africa by Kilburn et al. (2010: 25). We record this species from southern and central Mozambique.

\section{Remarks}

Phos elegantissimus is characterized by its rather broad shape with a conical spire in combination with striking red-brown spiral lines. The protoconch is large and purple. The body whorl is ornamented with fine primary spiral cords, which are red-brown coloured, with 3 to 7 fine, white, secondary cords in between. This species can be distinguished from all other known species of Phos by the combination of shell shape and pattern.

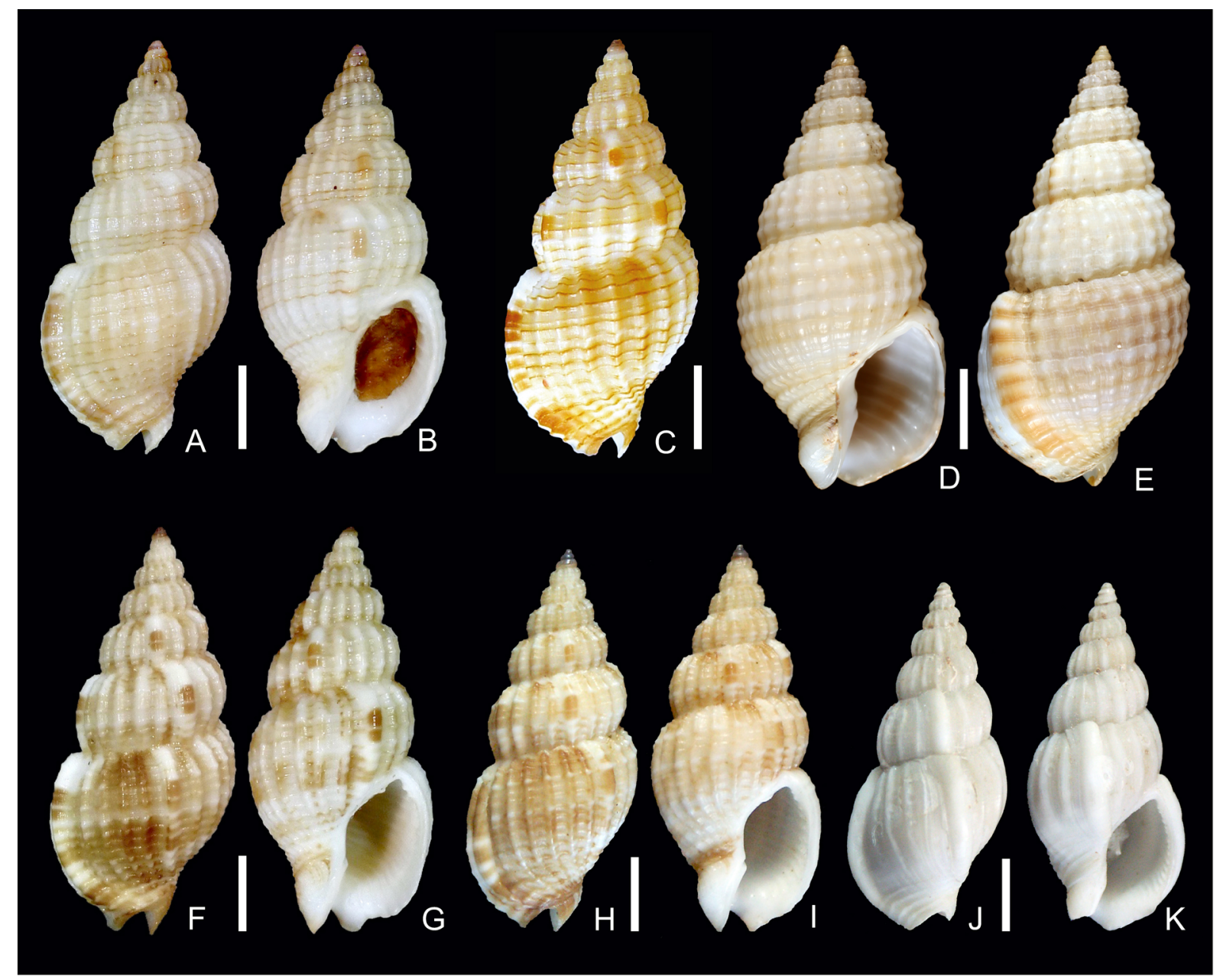

Fig. 1. A-C. Phos elegantissimus Hayashi \& Habe, 1965. A-B. Specimen from Mozambique, off North Quissico, depth 95-135 m, in trap, $23.8 \mathrm{~mm}$ long (JR). C. Specimen from Mozambique, off Sofala Bank, ex-pisces, depth 120-140 m, 24.8 mm long (JR). - D-E. Phos gemmulifer Kilburn, 2000, NW Mayotte, Mozambique Channel, BIOMAGLO stn DW4848, $12^{\circ} 35^{\prime} \mathrm{S}, 44^{\circ} 55^{\prime} \mathrm{E}$, depth $399-402 \mathrm{~m}$, $28.1 \mathrm{~mm}$ long (MNHN 2013-69815). - F-I. Phos hirasei G.B. Sowerby III, 1913. F-G. Specimen from Mozambique, off Sofala Bank, 200 $07^{\prime} \mathrm{S}, 36^{\circ} 09^{\prime}$ E, ex-pisces, depth 120-130 m, $26.3 \mathrm{~mm}$ long (JR). H-I. Specimen from South Africa, off Transkei, Msikaba, dredged at 90-110 m, $25.7 \mathrm{~mm}$ long (KF 4692). - J-K. Phos laevis Kuroda \& Habe, 1961, Madagascar, Campagne CREVETTIERE 1974 stn DC01, 12 $39^{\prime} \mathrm{S}, 48^{\circ} 16^{\prime}$ E, depth $240 \mathrm{~m}, 23.5 \mathrm{~mm}$ long (MNHN). Scale bars: $5.0 \mathrm{~mm}$. 
Phos (Greek, latinized to Phos, see Montfort 1810: 495) is masculine, as evidenced by the original combination in Montfort's type species (Phos senticosus). The word 'elegantissimum' is an adjective and it is therefore mandatory to correct the gender ending (to agree "with the generic name with which it is at any time combined" according to ICZN 31.2 and 34.2) to P. elegantissimus, as is also correctly done in the WoRMS database.

Phos gemmulifer Kilburn, 2000

Fig. 1D-E

Phos gemmulifer Kilburn, 2000: 204, figs 1-2.

Antillophos gemmulifer - Kilburn, Marais \& Fraussen 2010: 25.

\section{Type locality}

Southern Mozambique, Quissico-Zavora area, depth c. 200-300 m.

\section{Material examined}

MAYOTTE - 1 dd; NW Mayotte, Mozambique Channel, BIOMAGLO stn DW4848; $12^{\circ} 35^{\prime}$ S, 4455' E; depth 399-402 m; Jan. 2017; BIOMAGLO exped.; MNHN IM-2013-69815 (Fig. 1D-E).

MOZAMBIQUE • 3 lv; Quissico-Zavora; $25^{\circ} 10^{\prime} \mathrm{S}, 35^{\circ} 17^{\prime} \mathrm{E}$; depth 375-450 m; J. Rosado leg.; trawl;

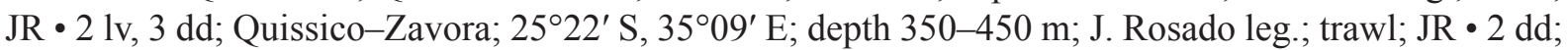
"Off Mozambique, by fishermen"; old collection; KF 3947 • 1 dd; same collection data as for preceding; KF 4816.

\section{Distribution}

Known from southern Mozambique only.

\section{Remarks}

This large species is characterized by its rather inflated shape with a moderately high spire and pronounced sculpture consisting of pronounced, widely spaced axial ribs that form big, rounded knobs when crossing the broad, flattened spiral cords. The colour of the shell is uniform white, cream to yellowish. No similar species in the western Indian Ocean are known to us.

Phos hirasei G.B. Sowerby III, 1913

Fig. 1F-I

Phos hirasei G.B. Sowerby III, 1913: 558.

Antillophos cf. hirasei - Kilburn, Marais \& Fraussen 2010: 26.

\section{Type locality}

Japan.

\section{Material examined}

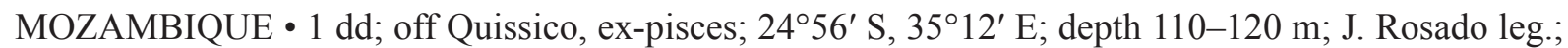
JR • 1 dd; Ponta Dobela, ex-pisces; 2632' S, 3258' E; depth 110-125 m; J. Rosado leg.; JR • 1 lv; NE Inhaca Island, among sponges; $25^{\circ} 50^{\prime} \mathrm{S}, 33^{\circ} 07^{\prime} \mathrm{E}$; depth 92-96 m; J. Rosado leg.; dredge; JR • 1 dd; off Sofala Bank, ex-pisces; 2007' S, 3609' E; depth 120-130 m; J. Rosado leg.; JR (Fig. 1F-G). 
SOUTH AFRICA • 1 dd; off Transkei, Msikaba; depth 90-110 m; 2004; F. Lorenz leg.; dredge; KF 4692 (Fig. 1H-I) • 2 lv; Natal, Umkomaas; depth 85-95 m; F. Lorenz leg.; dredge; KF 7982 - 2 lv; Mtwalume; $30^{\circ} 32^{\prime}$ S, 3044' E; depth 100-110 m; J. Rosado leg.; dredge; JR.

\section{Distribution}

Phos hirasei is well known in the West Pacific, where it is found from southern Japan in the north, along the Philippines and to New Caledonia in the south. The species was recorded from South Africa by Kilburn et al. (2010: 26) and we hereby confirm the records from East Africa and extend the range to Transkei (northeastern South Africa) and southern to central Mozambique.

\section{Remarks}

Phos hirasei is characterized by its irregular pattern, consisting of fine spiral lines alternating white (on top of the axial ribs) and brown (between the axials), often accentuated where the white spirals cross the large brown dots on the axial ribs, in combination with a dark purple protoconch.

Shell variability is suspiciously high in this species, but after studying hundreds of specimens from the entire Indo-West Pacific we are unable to conclude whether the many morphotypes reflect intraspecific variability or belong to distinct taxonomic units. Shells may differ considerably in density of sculpture, in thicknes, in size and in colour pattern. The species, however, seems to be monophyletic as far we can judge from molecular data collected up to now (Fraussen \& Galindo in prep.).

The few specimens from South Africa and Mozambique we studied all have a thick shell, a characteristic that we also observed in some populations off New Caledonia.

Phos laevis Kuroda \& Habe, 1961

Fig. 1J-K

Phos laeve Kuroda \& Habe in Habe, 1961: app. 20-21.

Phos laevie [sic] - Kuroda \& Habe in Habe 1961: 61, pl. 31, fig. 8.

\section{Type locality}

Japan, SW Shikoka, off Cape Ashizuri, 100-300 m.

\section{Material examined}

MADAGASCAR - $1 \mathrm{dd}$; Campagne CREVETTIERE 1974 stn DC01; 12 $32^{\prime} \mathrm{S}, 48^{\circ} 16^{\prime}$ E; depth 240 m; 1974; Campagne CREVETTIERE 1974 exped.; MNHN (Fig. 1J-K) • 1 dd; between Nosy Bé

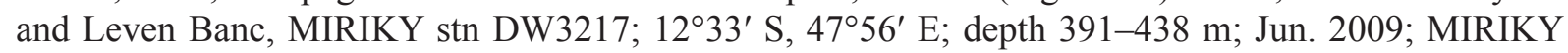
exped.; MNHN.

RÉUNION • 4 dd (3 jv); MD32 stn DC128; 2051’ S, 55³6' E; depth 280-340 m; 1982; MD32 exped.; MNHN.

\section{Distribution}

Formerly known from Japan and the Philippines, the species is here recorded from off Madagascar (Campagne CREVETTIERE 1974 stn DC01 and MIRIKY stn DW3217) and off Réunion island (MD32 $\operatorname{stn} \mathrm{DC} 128)$. 


\section{Remarks}

Phos laevis is characterized by its pale colour without pattern and moderately smooth shell with a glossy surface. Variability of the sculpture is high; some specimens are smooth without much spiral sculpture and with weak axial sculpture mainly on the upper spire whorls, while other specimens have well developed axial ribs; a few specimens have smooth but well visible spiral cords running along all whorls. Because an identical variability is observed in specimens from the western Pacific (Fraussen \& Galindo in prep.) we tentatively regard these specimens from the East Indian Ocean as conspecific with the West Pacific P. laevis.

Phos (Greek, latinized to Phos, see Montfort 1810: 495) is masculine, as evidenced by the original combination in Montfort's type species (Phos senticosus). The word 'laeve' is an adjective and it is therefore mandatory to correct the gender ending (to agree "with the generic name with which it is at any time combined" according to ICZN 31.2 and 34.2) to P. laevis, as is also correctly done in the WoRMS database.

\section{Phos ganii sp. nov. urn:lsid:zoobank.org:act:CADD5662-D4B1-4160-B2DE-ED8D470BF685}

Figs 2, 8

\section{Etymology}

Phos ganii sp. nov. is named to honour the late Gani Satar for his contributions to malacology, as he was one of the very first people who collected Mozambican shells. Gani passed away on April 19, 1998 in Mozambique.

\section{Material examined}

Holotype

MOZAMBIQUE • dd (27.2 mm); Mozambique Channel, Maputo transect, near Maputo, MAINBAZA stn CP3143; 2332' S, 3546' E; 264-277 m; Apr. 2009; MAINBAZA exped.; MNHN IM-2015-485 (Figs 2A-D, 8).

\section{Paratypes}

MADAGASCAR - 3 dd; Mozambique Channel, off Majenga; on Xenophora pallidula (Reeve, 1842), trawled in deep water; 2000; local fishermen leg.; paratypes 11-13; KF 2556 (Fig. 2K) 2 dd; same locality as for preceding; on Xenophora pallidula; 2000; local fishermen leg.; paratypes 14-15; KF $5236 \bullet 1 \mathrm{dd}$; from old collection; paratype 16; KF 7702.

MOZAMBIQUE $-1 \mathrm{dd}$; same collection data as for holotype; paratype 1; MNHN IM-2000-35085 (Fig. 2E-G) - 2 dd; S Mozambique, off Maputo; on Xenophora pallidula; depth 150-350 m; local fishermen leg.; trawl; paratypes 2-3; KF 5419 • 1 dd; S Mozambique, off Massinga; 2332' S, 35²47' E; 270-320 m; Nov. 2005; J. Rosado leg.; trawl; paratype 4; JR.

TANZANIA • 3 lv; S Tanzania, off North Rovuma River; 7²4' S, 3951' E; depth 330-360; Nov. 2005; Portuguese fishery vessel; trawl; paratypes 5-7; JR (paratype 5, Fig. 2H; paratype 6, Fig. 2I-J) • 3 dd; same collection data as for preceding; on Xenophora pallidula; paratypes 8-10; JR.

\section{Other material}

MOZAMBIQUE 11 fragment; off Maputo; on Xenophora pallidula; depth 150-350 m; local fishermen leg.; lot also contains paratypes 2-3; trawl; KF 5419. 


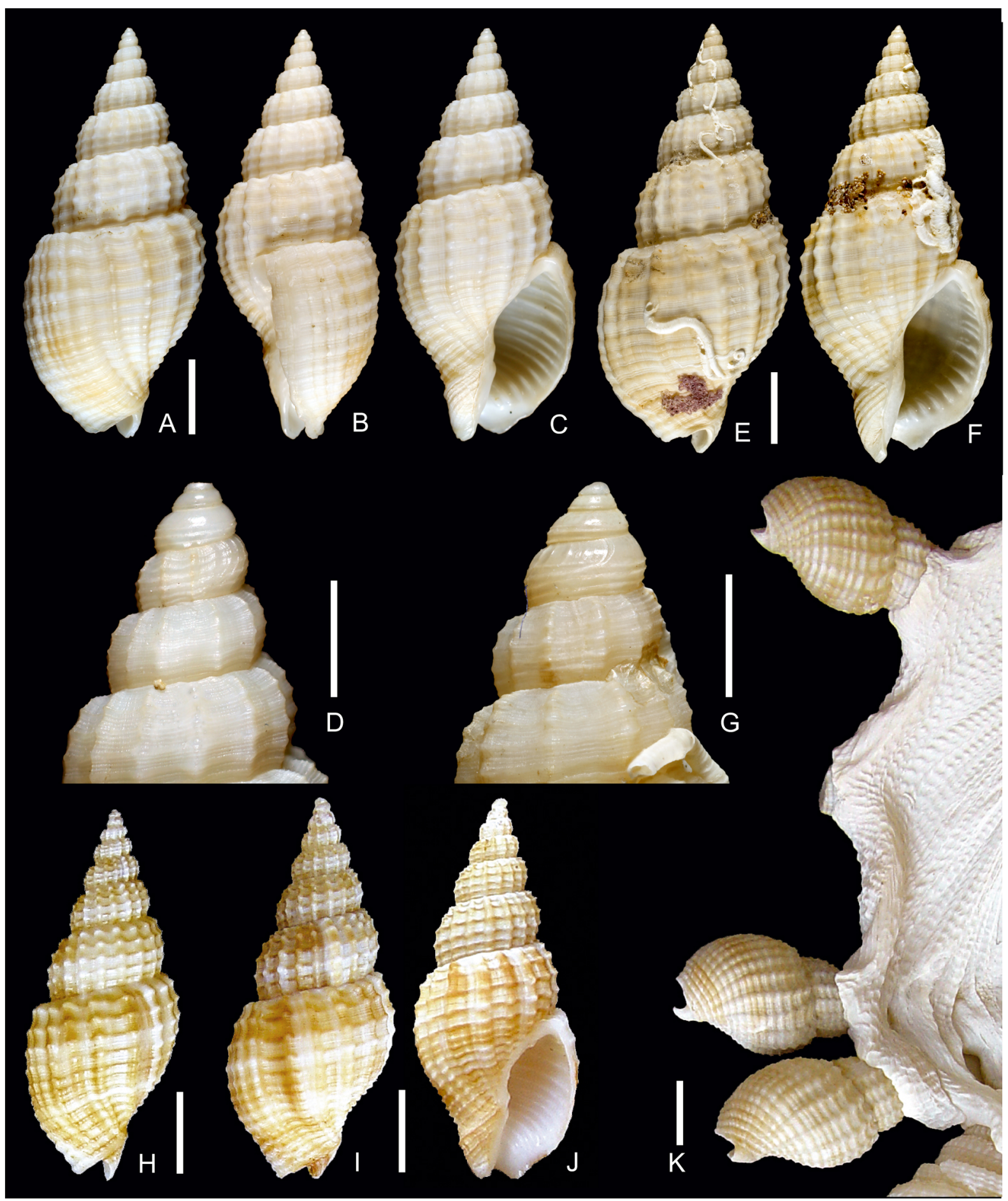

Fig. 2. Phos ganii sp. nov. A-C. Holotype, Mozambique Channel, Maputo transect, MAINBAZA stn

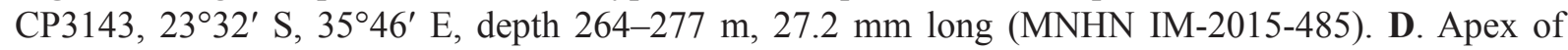
holotype. E-F. Paratype 1, same collection data as for holotype, $29.3 \mathrm{~mm}$ long (MNHN IM-200035085). G. Protoconch of paratype 1. H. Paratype 5, S Tanzania, off North Rovuma River, $7^{\circ} 24^{\prime}$ S, $39^{\circ} 51^{\prime}$ E, trawled by Portuguese fishery vessel, depth 330-360 m, $22.8 \mathrm{~mm}$ long (JR). I-J. Paratype 6, same collection data as for preceding, $23.4 \mathrm{~mm}$ long (JR). K. Paratypes 11-13, Madagascar, Mozambique Channel, off Majenga, trawled in deep water, on Xenophora pallidula (Reeve, 1842) (KF 2556). Scale bars: A-C, E-F, $\mathrm{H}-\mathrm{K}=5.0 \mathrm{~mm}$; D, G $=1.0 \mathrm{~mm}$. 


\section{Description (holotype)}

GeNERAL. Shell rather small for the genus, $27.2 \mathrm{~mm}$ in length. Shape broadly fusiform with moderately high spire, base stretched, giving a biconical appearance. Suture rather deep, accentuated by narrow, flattened shoulder of subsequent whorl. Sculpture cancellate, forming knobs where fine spiral sculpture crosses broader axial ribs. Colour white or yellowish to pale brown, spiral cords often brown (Fig. $2 \mathrm{~A}-\mathrm{C})$.

Protoconch (Fig. 2D). Multispiral, tip chipped, with 3 remaining whorls, total of about 33/4 whorls by estimation, $1.0 \mathrm{~mm}$ high, diameter $1.0 \mathrm{~mm}$; white with spiral cords of same colour, with 1 spiral cord initially concealed under suture with subsequent whorl, appearing on last half; second whorl with fine but sharp spiral cord, suprasuturally situated; this spiral cord more adapically situated along third whorl, with a second spiral cord appearing from below suture with subsequent whorl; last whorl with 3 such spiral cords, its last $1 / 4$ part with a few fine, opisthocline axial riblets adapically of those spiral cords. Transition to teleoconch marked by fine line and start of teleoconch sculpture.

TELEOCONCH. Consisting of $6 \frac{1}{2}$ weakly convex whorls. First teleoconch whorl starting with 6 fine spiral cords of which subsutural one weaker, their strength gradually increasing, with 1 fine secondary spiral thread appearing in interspaces. Second whorl with 6 such spiral cords, interspaces with 3 fine secondary spiral cords. Third whorl with 6 strong primary spiral cords, interspaces starting with 3 (in abapical interspaces) to 5 (in adapical interspaces) secondary spiral cords. Primary spiral cords gradually more pronounced along spire, but their number remaining constant. Penultimate whorl with 6 moderately large primary spiral cords; interspaces broad, with 3 (in abapical interspaces) to 5 (in adapical interspaces) secondary spiral cords (these cords quite difficult to count with precision). Body whorl with 15 spiral cords, 6 abapical ones moderately large with broad interspaces, on base only slightly weaker, with narrower interspaces with 1-3 fine secondary spiral cords.

APERTURE. Large, semi-oval but rather narrow for genus, adapically weakly pinched. Columella with 2 strong columellar folds. Parietal part straight. Adapical border of aperture broad, formed by shoulder of body whorl. Outer lip thick, with 13 or 14 thin but moderately sharp internal lirae, extending far into aperture; edge sharp. Aperture with siphonal canal more than $2 / 5$ of total shell length. Siphonal canal rather long for genus, broad, open, covered by fine spiral cords on outside.

\section{Distribution and habitat}

Known from deep water in Mozambique Channel (Mozambique and Madagascar) in the south to southern Tanzania in the north (Fig. 8).

Live-collected specimens were found at between 330 and $360 \mathrm{~m}$ in Tanzania and empty shells between about 264 and $800 \mathrm{~m}$.

The species is found attached to Xenophora pallidula quite frequently and according to our observations more often than for other deep-water Nassariidae and Buccinidae. Besides being a useful secondary collecting method (Terryn 2008: 1-4) this also may throw some light on habitat characteristics.

\section{Remarks}

Phos ganii sp. nov. is characterized by its somewhat biconical shape and deep suture, the usually constant number of 6 primary spiral cords, the moderately large knobs, formed where spiral and axial sculptures cross, and by the rather narrow aperture with moderately long siphonal canal. The shape is reminiscent of that in the Carribean genus Antillophos (Galindo et al. 2016) in outline and sculpture.

The colour is usually white or yellowish to pale brown (see holotype), while fresh specimens (paratypes $5,7,11-13,16)$ may be slightly darker with 3 broad but only slightly darker spiral bands. 
The number of fine secondary spiral cords on the base is usually $1-3$, in some paratypes they occasionally grow up to 4.

Variability in sculpture is low while size may vary considerably; paratypes 5-7 (22.8-25.1 mm) have 6 to $6 \frac{1}{2}$ whorls, paratypes $11-13(21.3-23.2 \mathrm{~mm})$ are only slightly smaller but have about $5 \frac{1}{2}$ whorls.

Phos durianoides (Fraussen \& Poppe, 2005) looks similar but differs from P. ganii sp. nov. by its rather semi-oval shape, the strong knobs where spiral and axial sculptures cross and the broad secondary spiral cords with a fine groove as interspace.

Phos gemmulifer Kilburn, 2000 (Fig. 1D-E) differs from P. ganii sp. nov. by its broader shape, thicker shell, larger knobs and larger size.

Phos retecosus Hinds, 1844 (type locality: "Ceylon") differs from P. ganii sp. nov. by its broader shape, the smoother subsutural area, the presence of brown lines on top of the spiral cords and some brownish bands on the body whorl and on the labral varix. The size is slightly larger.

\section{Phos geminus sp. nov. urn:lsid:zoobank.org:act:E6D82CCC-E989-4698-8A11-13390204B588}

Figs 3,8

Phos roseatus (part) - all authors referring to African fauna [non Hinds, 1844].

Antillophos roseatus (part) - all authors referring to African fauna, including Kilburn, Marais \& Fraussen 2010: 26 [non (Hinds, 1844)].

\section{Etymology}

The specific epithet of this species is derived from the Latin adjective 'geminus', - $a$, -um, meaning 'born together' or 'twin', which refers to its morphological similarity to its putative sister species, P. roseatus.

\section{Material examined}

\section{Holotype}

MADAGASCAR - dd (27.9 mm long); off Fort Dauphin, ATIMO VATAE stn CP3509; $25^{\circ} 15^{\prime} \mathrm{S}$, 4707' E; depth 78-79 m; Apr. 2010; ATIMO VATAE exped.; MNHN IM-2000-35086 (Figs 3A-C, 8).

\section{Paratypes}

MADAGASCAR - MIRIKY Exped. • 1 dd; Mahajamba Bay, stn DW3244; 145ㅗ' S, 46 $55^{\prime}$ E; depth 58-87 m; Jul. 2009; MIRIKY exped.; paratype 1; MNHN IM-2007-38263 (Fig. 3D-F) • 1 dd; off Naredny Banc, stn CP3287; 14 ${ }^{\circ} 34^{\prime}$ S, 47 ${ }^{\circ} 28^{\prime}$ E; depth 48-54 m; Jul. 2009; MIRIKY exped.; paratype 2; MNHN IM-2007-36694 • 1 dd; S of Cape Saint-Sébastien, stn CP3205; $12^{\circ} 38^{\prime}$ S, 48 $26^{\prime}$ E; depth 60-63 m; Jun. 2009; MIRIKY exped.; paratype 3; KF $7865 \bullet 1 \mathrm{dd}$; same collection data as for preceding; paratype 4; JR.

\section{Other material}

CHAGOS ARCHIPELAGO • 1 lv (jv); off Chagos Archipelago; deep water; ex-USSR fishing vessel; KF 4462.

EGYPT • 4 dd (1 jv); 35 km S of Hurgada, Makadi Bay; shallow water; May 2001; crabbed; KF 4464.

MADAGASCAR • 1 dd; Tulear, Tulear stn 899.14; Feb. 1962; Thomassin leg.; MNHN • 3 lv; Tulear Bay, Pointe Anosy, sandflats at low tide; Von Cosel leg.; MNHN • 11 lv; off Tulear; 2002-2004; local fishermen leg.; KF 4066. - MIRIKY Exped. • 1 dd; Leven Banc, stn CP3189; $12^{\circ} 30^{\prime}$ S, $48^{\circ} 18^{\prime}$ E; depth 
346-376 m; Jun. 2009; MIRIKY exped.; MNHN • 3 dd (1 jv); Cape St. Andre, stn DW3197; 1207' S, 48 58' E; depth 362-431 m; Jun. 2009; MIRIKY exped.; MNHN • 2 dd; stn DW3199; $12^{\circ} 06^{\prime}$ S, 48 57’ E; depth 527-652 m; Jun. 2009; MIRIKY exped.; MNHN • 4 dd; Cape St. Sébastian, stn CP3205; $12^{\circ} 38^{\prime} \mathrm{S}, 48^{\circ} 26^{\prime} \mathrm{E}$; depth 60-63 m; Jun. 2009; MIRIKY exped.; MNHN • 2 dd; between Nosy Bé and

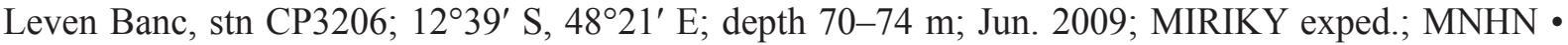
1 dd; stn CP3209; 1243' S, 48¹4' E; depth 291-353 m; Jun. 2009; MIRIKY exped.; MNHN. - off Naredny Banc, MIRIKY Exped. • 1 dd; stn DW3237; 14³1' S, 47²5' E; depth 50-107 m; Jul. 2009; MIRIKY exped.; MNHN • 3 dd; stn DW3238; 14²9' S, 47²7' E; depth 48-139 m; Jul. 2009; MIRIKY

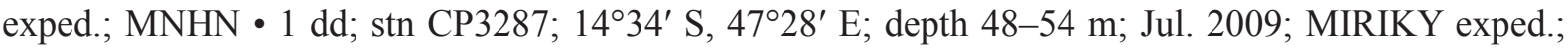
MNHN • 9 dd; stn CP3288; 1432' S, 47²6' E; depth 46-54 m; Jul. 2009; MIRIKY exped.; MNHN •

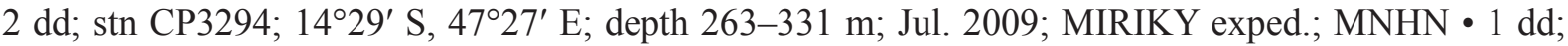
Mahajamba Bay, stn DW3244; 145' S, 465' E; depth 58-87 m; Jul. 2009; MIRIKY exped.; MNHN • 3 dd; stn CP3285; 144ㄱ' S, 4658' E; depth 512-680 m; Jul. 2009; MIRIKY exped.; MNHN • 1 dd; off

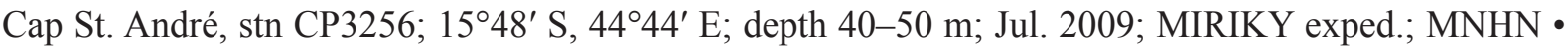

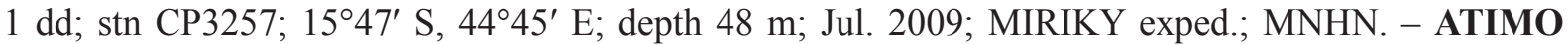
VATAE Exped. $\cdot 1$ dd; between Lokaro and St. Luce, stn DW3515; $24^{\circ} 53^{\prime} \mathrm{S}, 4^{\circ} 28^{\prime} \mathrm{E}$; depth $184-203 \mathrm{~m}$; Apr. 2010; ATIMO VATAE exped.; MNHN • 2 dd; Cape Andavaka, stn CP3548; 2517' S, 46 $34^{\prime}$ E; depth 63-66 m; Apr. 2010; ATIMO VATAE exped.; MNHN • 1 dd; Fort Dauphin, stn CP3509; $25^{\circ} 15^{\prime}$ S,

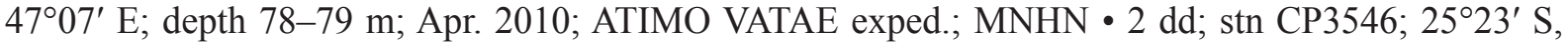
464' E; depth 84-85 m; May 2010; ATIMO VATAE exped.; MNHN • $1 \mathrm{dd}$; stn CP3569; $25^{\circ} 05^{\prime} \mathrm{S}$, 4705' E; depth 69-70 m; May 2010; ATIMO VATAE exped.; MNHN • 2 lv, 8 dd (2 jv); stn CP3571; $25^{\circ} 08^{\prime} \mathrm{S}, 47^{\circ} 09^{\prime} \mathrm{E}$; depth $77 \mathrm{~m}$; May 2010; ATIMO VATAE exped.; MNHN -2 lv, $10 \mathrm{dd}(2 \mathrm{jv}) ;$ stn CP3572; $25^{\circ} 08^{\prime}$ S, $47^{\circ} 09^{\prime}$ E; depth 77 m; May 2010; ATIMO VATAE exped.; MNHN • 1 dd; stn CP3573; $25^{\circ} 13^{\prime} \mathrm{S}$, 47²14' E; depth 87-88 m; May 2010; ATIMO VATAE exped.; MNHN.

MOZAMBIQUE - 4 dd (1 jv); Inhaca Island, $\mathrm{N}$ of La Passe, INHACA stn MD13-14; $26^{\circ} 03^{\prime} \mathrm{S}$, $33^{\circ} 01^{\prime}$ E; depth 50-53 m; Nov. 2011; INHACA exped.; MNHN • 10 lv; Nacala Bay, shallow water; local collector; KF 0937 (Fig. 3G-J) • 2 lv; same collection data as for preceding; KF 4878.

SEYCHELLES - 1 lv; off Mahé, deep water; 2010; trap; KF 7866. - REVES-2 Exped. • 1 dd; stn 5;

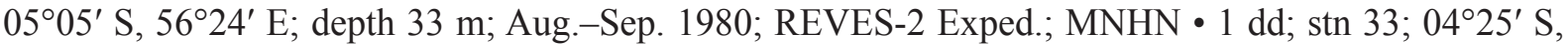

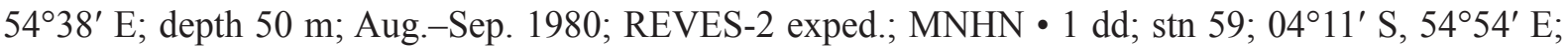
depth 50 m; Aug.-Sep. 1980; REVES-2 exped.; MNHN.

SOMALIA • 1 lv; off Ras Hafun, deep water; fishermen leg.; trawl; KF $6689 \bullet 1$ dd; Negros Bay; depth 12-25 m; 1993; dredge; KF $3304 \cdot 2$ dd; offshore, deep water; fishermen leg.; trawl; KF 2923 • 2 dd; same collection data as for preceding; KF 4152.

SOUTH AFRICA • 1 dd; Natal, off Durban; depth 75-80 m; 1982; D. and M. Meyer; dredge; KF 4262.

UNITED ARAB EMIRATES • 6 dd; Gulf of Oman, Dibba; $25^{\circ} 36.07^{\prime}$ N, 56 $20.44^{\prime}$ E; Feb. 2014; I. Kurtz leg.; crabbed or in sand brought from deep water with sand for beach of Radisson Blu Hotel; KF $7819 \bullet 1 \mathrm{dd}$; same collection data as for preceding; KF 7826.

\section{Description (holotype)}

General. Shell of medium size, length $27.9 \mathrm{~mm}$, moderately thin but solid (Fig. 3A-C). Shape slender with acute spire; whorls convex; body whorl rather stretched, with weak shoulder. Axial sculpture dominant. Colour pale brown, tending to orange, spire whorls with one moderately broad, slightly darker band, body whorl with 3 such bands, one suprasutural primary spiral cord clearly paler; axial and spiral sculpture accentuated by slightly paler knobs on top of axial ribs, varices and some axials slightly paler to white. 


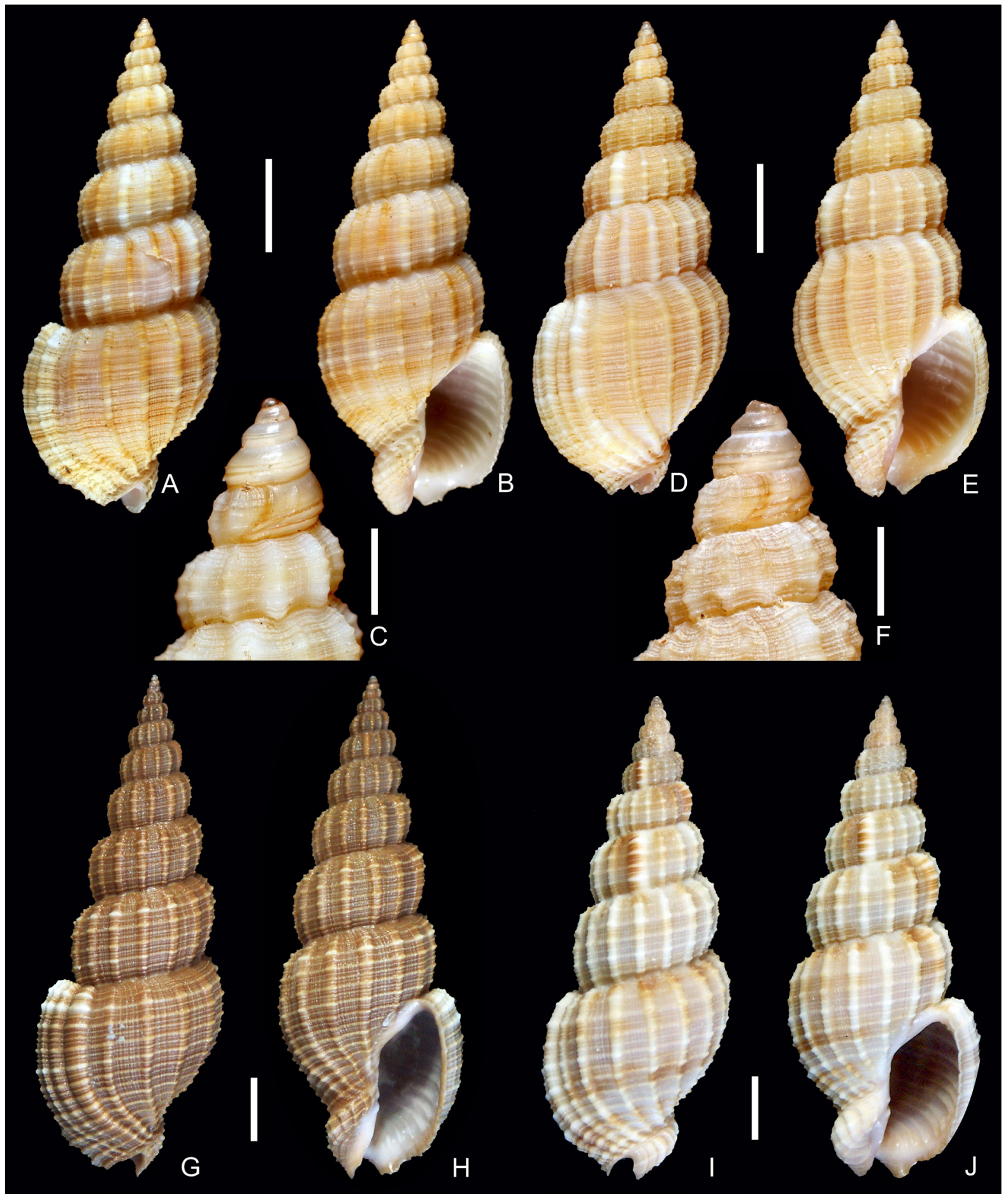

Fig. 3. Phos geminus sp. nov. A-B. Holotype, Madagascar, off Fort Dauphin, ATIMO VATAE stn

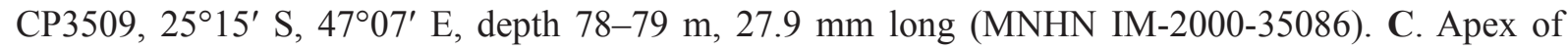

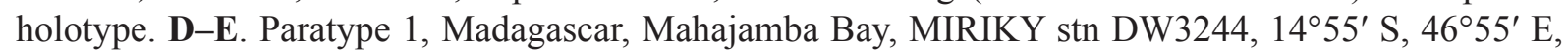
depth 58-87 m, 27.0 mm long (MNHN IM-2007-38263). F. Apex of paratype 1. G-H. Specimen from Mozambique, Nacala Bay, shallow water, $40.2 \mathrm{~mm}$ long (KF 0937). I-J. Specimen with same collection data as for preceding, $38.3 \mathrm{~mm}$ long (KF 0937). Scale bars: A-B, D-E, G-J = 5.0 mm; C, F = $1.0 \mathrm{~mm}$. 
Protoconch (Fig. 3C). Pale multispiral, consisting of about 4 whorls, tip usually slightly eroded or chipped, $1.5 \mathrm{~mm}$ high, diameter $1.2 \mathrm{~mm}$; colour yellowish to pale brown, spiral bands slightly darker. First whorls smooth, glossy; third whorl with weak angulation at mid-whorl, turning into 2 spiral cords; spiral cords gradually more abapically situated, fourth whorl with 2 brown spiral cords; last 1/6 whorl with a few strongly opisthocline axial riblets adapically of those spiral cords. Transition to teleoconch marked by a single red-brown opisthocline axial line.

Teleoconch. Consisting of 7 convex whorls. First teleoconch whorl with 4 primary spiral cords, interspaces broad with 1 fine secondary spiral thread. Fifth primary spiral cord appearing along abapical suture of second teleoconch whorl, interspaces with 3 secondary spiral cords of which middle one usually slightly stronger. Middle secondary spiral cords gradually increasing in strength, resulting in 23 alternating fine and finer spiral cords on penultimate whorl, including 5 slightly stronger ones (primary spiral cords) with 3 slightly finer, but unequal in strength, secondary spiral cords in interspaces. Body whorl with 15 primary and 34 secondary spiral cords, on base towards siphonal canal growing larger. First teleoconch whorl with 11 sharp axial ribs including 1 slightly stronger varix, second and third whorl with 12 axial ribs including 1 (on second whorl) or 2 (on first whorl) slightly stronger varices. Their number only weakly increasing, penultimate whorl with 13 axial ribs, occasionaly with a single weak varix. Body whorl with 19 axial ribs, including 4 that form a broad prelabral varix.

APERTURE. Columella rather straight, gently curved towards an also straight parietal part. Adapical border of aperture broad, formed by shoulder of body whorl. Columella smooth, transition to siphonal canal with 1 weak columellar fold. Outer lip with 14 thin but moderately sharp internal lirae, extending far into aperture. Outer lip thick, edge sharp, with weak notch along siphonal canal. Aperture with siphonal canal about $1 / 3$ of total shell length. Siphonal canal twisted, short, broad, open, on outside covered by sharp sculpture.

\section{Distribution and habitat}

This species is restricted to the western Indian Ocean along the East Africa coast, from South Africa in the south to the Red Sea in the north (Fig. 8), living in sand. it is syntopic with Phos retecosus Hinds, 1844 off Chagos Archipelago (KF 1636), with P. rhodostoma Von Martens, 1880 at Nacala Bay (KF 2232, KF 3035, KF 4763) and with P. ladoboides sp. nov. (Fig. 4A-J) at the Seychelles (REVES-2 stn 5 and KF 6126).

\section{Remarks}

Phos geminus sp. nov. is a large species, up to $37 \mathrm{~mm}$ long, characterized by its slender shape with an acute spire and rather narrow body whorl and by the sharp, cancellate sculpture.

Little variability in shape and sculpture is observed. The middle secondary spiral cords may become almost as strong as the primary spiral cords (see holotype), resulting in 23 alternating fine and finer spiral cords on the penultimate whorl; in other specimens these middle secondary spiral cords may be only slightly stronger, resulting in 5 primary spiral cords with 3 finer secondary spiral cords in the interspaces (see paratype 1, Fig. 3D-E). The number of columellar folds at the transition to the siphonal canal may vary from 1 (see holotype) to, occasionally, 2 (see paratype 1). The colour, however, may range from white and yellowish over pink (Fig. 3I-J) and orange or purplish to dark chocolate brown (Fig. 3G-H).

All authors working with African Photinae have until now referred specimens of this species to Phos roseatus Hinds, 1844. This misidentification is listed in almost every work that covers the Indo-Pacific Ocean. However, P. roseatus from the eastern Indian Ocean and western Pacific differs from P. geminus sp. nov. in its sligtly broader shape, with axial ribs that are slightly broader on the penultimate and body whorls and fewer in number. The weak conchological differences between $P$. geminus sp. nov. and 
$P$. roseatus are the reason why the new species has escaped the attention of most scientists and collectors. The differences in shape and axial sculpture, however, are consistent and one is able to recognize and separate both morphotypes even with a limited amount of material.

Phos ladoboides sp. nov. urn:1sid:zoobank.org:act:D4C1306E-9F13-48A5-B45B-EB3840539538

Figs 4, 9

\section{Etymology}

Phos ladoboides sp. nov. is named after the local dish, 'ladob', the contemporary desert version made from plantain (a kind of banana) and sweet potatoes with coconut milk, nutmeg and vanilla or sugar. The colour of the shell, often yellowish as a banana, often brownish-range as some sweet potatoes, with brown dots like nutmeg or with white bands or white axial ribs like coconut milk and vanilla or sugar, remind us of this dish.

\section{Material examined}

\section{Holotype}

SEYCHELLES • lv (22.4 mm long); REVES-2 stn 31; 04³6' S, 54²0' E; depth 38 m; Aug.-Sep. 1980; REVES-2 exped.; MNHN IM-2015-482 (Figs 4A-C, 9).

\section{Paratypes}

SEYCHELLES • 8 lv; same collection data as for holotype; paratypes 1-8; MNHN IM-2000-28504 (Fig. 4D-E, paratype 1) $11 \mathrm{lv}$; same collection data as for holotype; paratype 9; JR 3 lv; off Mahé; deep water; 2010; crayfish trap; paratypes 10-12; KF 6126 (Fig. 4F-J) • 5 dd; Mahé; 1967; paratypes 13-17; KF 0455.

\section{Other material}

MAURITIUS • 1 dd; St. Brandon, St. Brandon Shoal, in coral rubble; shallow water; 2014; F. Lorenz leg.; KF 7980.

SEYCHELLES • 5 dd; off Mahé; 1967; old collection; KF 0455 • 3 lv; off Mahé; deep water; 2010; crayfish traps; KF 6126. - REVES-2 Exped. -5 lv, 1 dd; stn 5; 050 $05^{\prime}$ S, 56 $6^{\circ} 24^{\prime}$ E; depth 33 m; Aug.-

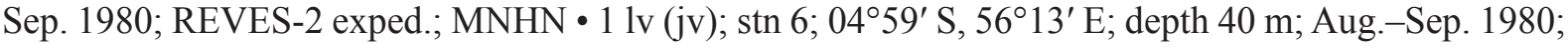
REVES-2 exped.; MNHN • 1 lv; stn 13; 0520' S, 56²0' E; depth 53 m; Aug.-Sep. 1980; REVES-2

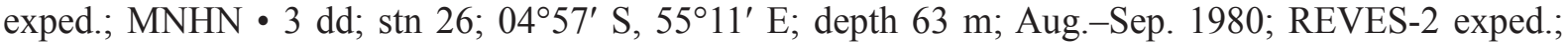

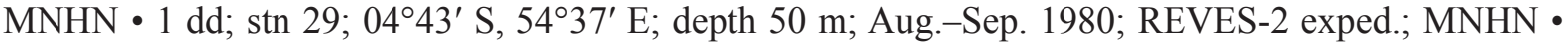

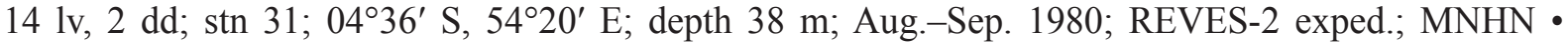

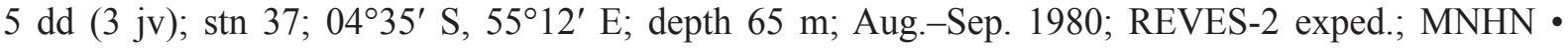

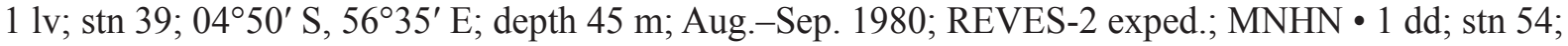

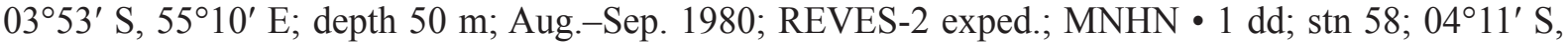

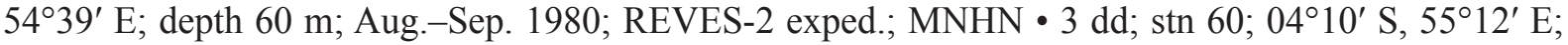

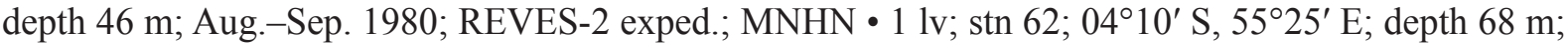
Aug.-Sep. 1980; REVES-2 exped.; MNHN.

\section{Description (holotype)}

General. Shell of medium size for the genus, $22.4 \mathrm{~mm}$ in length. Shape fusiform with moderately high spire. Colour yellowish brown, primary spiral cords off-white to white (Fig. 4A-C).

Protoconch. Large, multispiral, consisting of 4 whorls; eroded, tip chipped, $3 \frac{1}{2} 2$ whorls remaining but number of whorls countable; diameter $1.6 \mathrm{~mm}$, remaining whorls $1.7 \mathrm{~mm}$ in length, diameter $1.6 \mathrm{~mm}$. First whorl convex, smooth, glossy. A single, fine but sharp spiral cord appearing along second whorl. 
A second spiral cord appearing along third whorl. Last $1 / 2$ part of last protoconch whorl with 3 fine but sharp spiral cords and several strongly opisthocline axial ribs that become well pronounced. Transition to teleoconch marked by pronounced opisthocline rib followed by start of teleoconch sculpture.

Teleoconch. Consists of about 5 $1 / 2$ rather convex whorls. Sculpture rather reticulate, with fine spiral cords that form a sharp knob when crossing otherwise rather smooth axial ribs. First teleoconch whorl ornamented with 6 fine primary spiral cords, including 2 finer ones along subsutural slope; interspaces broad, starting with a single fine secondary thread but suddenly increasing to 3 . Strength of primary spiral cords increasing along second whorl. Third whorl with 6 rather fine but sharp primary spiral cords; interspaces broad with 3 secondary spiral cords of which central one slightly stronger. Number

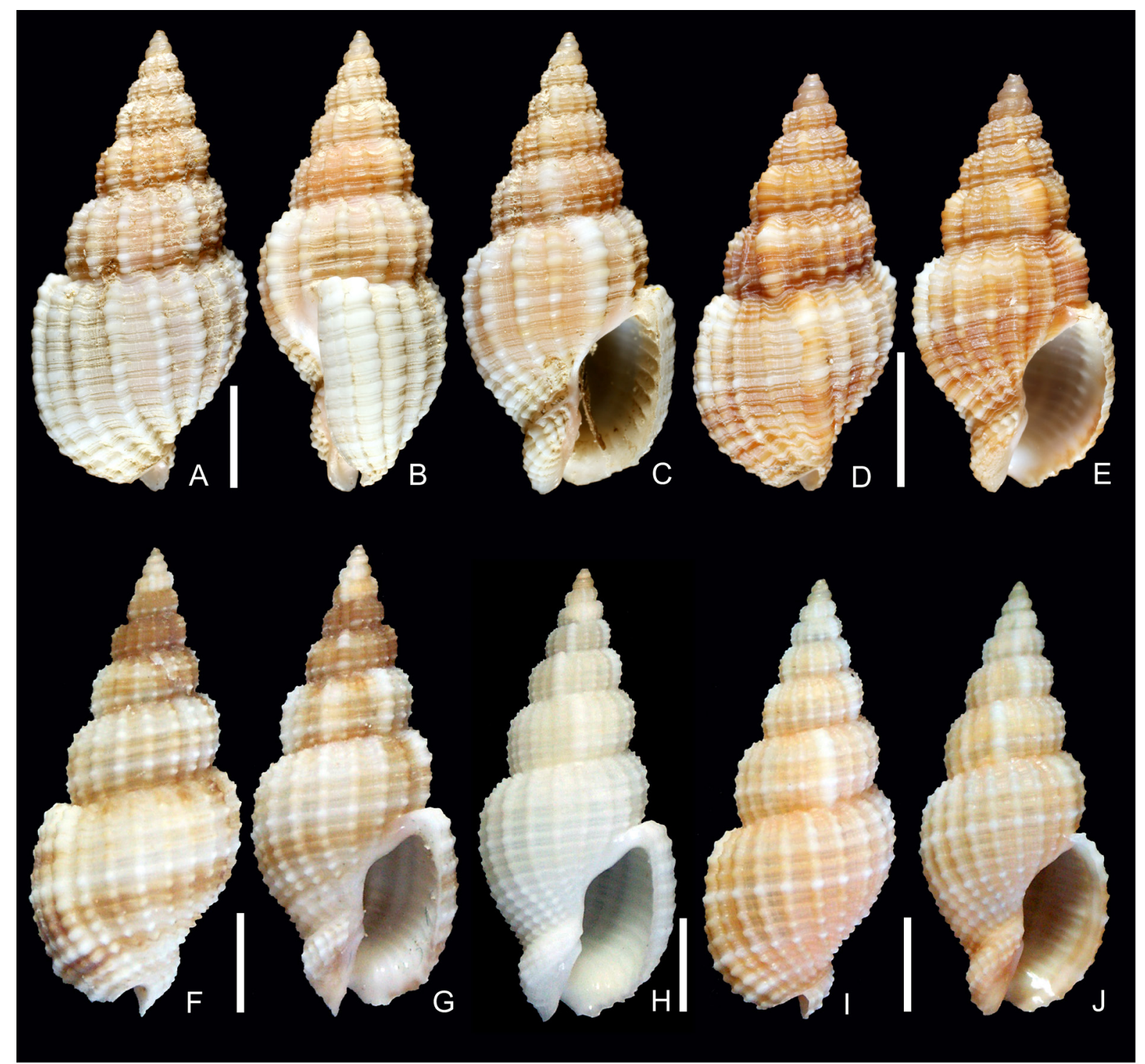

Fig. 4. Phos ladoboides sp. nov. A-C. Holotype, Seychelles, REVES-2 stn $31,04^{\circ} 36^{\prime} \mathrm{S}, 54^{\circ} 20^{\prime}$ E, depth $38 \mathrm{~m}, 22.4 \mathrm{~mm}$ long (MNHN IM-2015-482). D-E. Paratype 1, same collection data as for holotype, $15.3 \mathrm{~mm}$ long (MNHN IM-2000-28504). F-G. Paratype 11, Seychelles, off Mahé, in crayfish trap, deep water, $24.0 \mathrm{~mm}$ long (KF 6126). H. Paratype 12, same collection data as for preceding, $25.2 \mathrm{~mm}$ long (KF 6126). I-J. Paratype 10, same collection data as for preceding, $23.5 \mathrm{~mm}$ long (KF 6126). Scale bars: $5.0 \mathrm{~mm}$. 
of secondary spiral cords increasing to 5 in middle interspace only. Primary spiral cords slightly broader along penultimate whorl, occasionally slightly flatter. Body whorl with 13 moderately broad, slightly flattened spiral cords, including 2 slightly finer ones along subsutural slope; interspaces broad, with 3 fine secondary spiral cords (5 in middle interspace); subsutural interspaces narrow. First teleoconch whorl with about 12 sharp axial ribs, including 1 white varix. Number of axial ribs only slightly increasing up to 14 along other whorls, including 2 (on penultimate whorl) or 3 (on other whorls) varices. Body whorl with 14 axial ribs, including 1 varix; apertural varix large, broad.

APERTURE. Semi-ovate; white, outer lip occasionally with narrow brownish border according to pattern of outer surface. Outer lip with 12 fine but sharp internal lirae. Columella with 2 moderately strong columellar folds at transition to siphonal canal. Lip thin, edge sharp, without siphonal notch. Siphonal canal open, broad, short, typical of the genus.

\section{Distribution and habitat}

Known from deep water off the Seychelles Archipelago and a single specimen from St. Brandon (Fig. 9).

Syntopic with P. geminus sp. nov. (REVES-2 stn 5, KF 7866).

\section{Remarks}

Phos ladoboides sp. nov. is characterized by its rather broad shape with a short spire, the sharp, reticulate sculpture, the rather large protoconch and the banded pattern. The shell is of medium size for the genus (up to $25.2 \mathrm{~mm}$ in length, usually between 19 and $23 \mathrm{~mm}$ ).

The colour is highly variable, ranging from white (Fig. 4H), over yellowish and uniform orange-brown to dark brown with a pattern of broad bands. When patterned (Fig. 4F-G), then with a single broad, brown to dark brown spiral band along the spire whorls, this broad band often becoming much finer along the body whorl; body whorl usually with 3 brown to dark brown spiral bands, the band along the base being the broadest, occasionally with one of those bands missing; occasionally with a narrow brown subsutural spiral band which suddenly ends in a white dot before the prelabral varix.

The spiral sculpture shows little variation. The first teleoconch whorl is usually ornamented with 6 fine primary spiral cords (see the holotype), occasionally with 7 (see paratype 2 ). The third whorl has 6 (holotype) or 7 (paratypes 1-2) rather fine but sharp primary spiral cords. The interspaces are broad, with 3 secondary spiral cords of which the central one is slightly stronger. The interspace situated at the middle of the whorl usually has 5 instead of 3 such secondary spiral cords, an increase that may start along the $3^{\text {rd }}$ teleoconch whorl (see holotype) or along the penultimate whorl (see paratype 1 ). The number of axial ribs varies only slightly, from 13 (paratype 1) to 14 (holotype).

Phos geminus sp. nov. differs from P. ladoboides sp. nov. by its slender shape with a higher spire, the somewhat stretched base, the lower number of spiral cords in combination with a higher number of axial ribs, the usually more uniform colour and the usually larger adult size.

Phos verbinneni (Fraussen, 2009) from the Philippines looks identical in sculpture and pattern but differs from $P$. ladoboides sp. nov. by its slightly larger protoconch in combination with a lower number of teleoconch whorls (slightly more than $4 \frac{1}{2}$ instead of $5 \frac{1 / 2}{-6}$ for shells of about the same size), the transition to the teleoconch that is marked by a straight rib (instead of a strongly opisthocline one), the slightly higher number of spiral cords along the penultimate whorl (8 instead of 6-7) and the slightly higher number of axial ribs. Only a single specimen of $P$. verbinneni is known at the present and therefore no information about variabity within that species is known. 
Phos pulchritudus sp. nov. urn:1sid:zoobank.org:act:2ECFAD36-9EB6-4BEC-A92C-3EF529AE9990

Figs $5 \mathrm{~A}-\mathrm{F}, 9$

\section{Etymology}

The specific epithet of Phos pulchritudus sp. nov. is derived from the Latin 'pulchritudo', meaning 'beauty', 'attractive', for the remarkable beauty of this shell.

\section{Material examined}

Holotype

MADAGASCAR - dd (28.6 mm long); off S Madagascar, ATIMO VATAE stn CP3622; $25^{\circ} 43.0^{\prime} \mathrm{S}$, 4559.4' E; depth 84-88 m; May 2010; ATIMO VATAE exped.; MNHN IM-2015-486 (Figs 5A-D, 9).

\section{Paratypes}

MADAGASCAR • 2 lv; S Madagascar, ATIMO VATAE CP3560; $25^{\circ} 37^{\prime} \mathrm{S}, 46^{\circ} 10^{\prime} \mathrm{E}$; depth $102-106 \mathrm{~m}$; May 2010; ATIMO VATAE exped.; paratypes 1-2; MNHN IM-2000-35088 • 1 dd; S Madagascar, off Narendry Bay, MIRIKY stn DW3237; 14³1' S, 47²5' E; depth 50-107 m; Jun. 2009; MIRIKY exped.; paratype 3; MNHN IM-2000-35089.

MOZAMBIQUE • 1 1v; S Mozambique, S of Ponta Mucombo; $26^{\circ} 18^{\prime} \mathrm{S}, 33^{\circ} 00^{\prime} \mathrm{E}$; depth 87-90 m; Jan. 2018; J. Rosado leg.; dredge; paratype 4; JR • 1; S Mozambique, Ponta Abril; $26^{\circ} 08^{\prime} \mathrm{S}, 33^{\circ} 01^{\prime}$ E; depth 78-86 m; J. Rosado leg.; dredge; paratype 5; JR • 1; S Mozambique, S Quissico; 250' S, 34² ${ }^{\prime}$ E; depth 105-135 m; J. Rosado leg.; trap; paratype 6; JR • 1 dd; S Mozambique, S of Inhambane, ex-pisces; depth 90-145 m; J. Rosado leg.; paratype 7; LR • 1 dd; S Mozambique, Zavora Point; $24^{\circ} 36.7^{\prime} \mathrm{S}, 35^{\circ} 22.0^{\prime}$ E, ex-pisces; depth 85-120 m; May 2009; J. Rosado leg.; paratype 8; JR • 2 dd; S Mozambique, NE Inhaca Island; $25^{\circ} 49^{\prime} \mathrm{S}, 33^{\circ} 07^{\prime} \mathrm{E}$; depth 87-94 m; Jan. 2016; J. Rosado leg.; dredge;

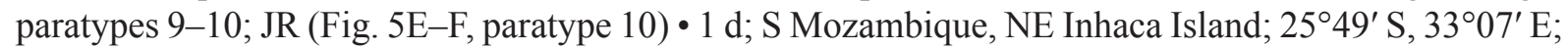
depth 87-94 m; Nov. 2015; J. Rosado leg.; dredge; paratype 11; SG • 1 dd; S Mozambique, NE Inhaca Island; $25^{\circ} 49^{\prime} \mathrm{S}, 33^{\circ} 07^{\prime} \mathrm{E}$; depth 87-94 m; Nov. 2015; J. Rosado leg.; dredge; paratype 12; AS • 2; S Mozambique, Ponta Abril; $26^{\circ} 08^{\prime} \mathrm{S}, 33^{\circ} 01^{\prime} \mathrm{E}$; depth 78-86 m; J. Rosado leg.; dredge; paratypes

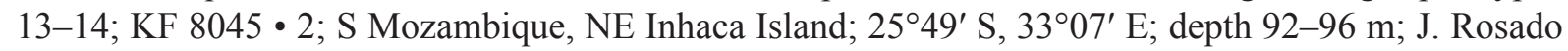
leg.; dredge; paratypes 15-16; KF 7981.

\section{Description (holotype)}

General. Shell of medium size, $28.6 \mathrm{~mm}$ in length, thin but solid (Fig. 5A-D). Shape fusiform with high spire; whorls rather convex; suture conspicious, accentuated by small notch formed where axial sculpture suddenly stops; base stretched. Colour and pattern rather bright. First 2 teleoconch whorls pinkish; last 4 teleoconch whorls pale yellowish, with 3 broad spiral bands. Subsutural spiral band pale brownish, darker on abapertural slope towards axial rib, paler or white on adapertural slope behind axial rib, but white when crossing a varix. Middle band pale, inconspicious, along penultimate whorl darker when crossing a varix. Suprasutural band along spire partly concealed under suture of subsequent whorl, along body whorl rather broad, occasionally interrupted, usually darker when crossing axial ribs or a varix. Those 3 spiral bands with some pink tinges in between. Spiral sculpture situated on those 3 spiral bands ornamented with interrupted lines of small brown specks, spiral sculpture situated in pale interspaces pale. Apertural varix with pink dots where those 3 spiral bands stop, adjacent anal notch and siphonal canal pink; inside aperture white to yellowish, with some pink tinges.

Protoconch (Fig. 5D). Multispiral, tip chipped, with 3 remaining whorls, total of about $3 \frac{1}{2}$ whorls by estimation, $1.5 \mathrm{~mm}$ high, diameter $1.4 \mathrm{~mm}$; colour usually pale yellowish with spiral cords of same colour. First remaining whorl well convex, smooth, glossy, with 1 spiral cord partly concealed under 
suture with subsequent whorl; this spiral cord becoming situated more adapically, thus above suture on second whorl; one additional sharp spiral cord appearing along second whorl; third whorl with 2 spiral cords, last $1 / 8$ whorl with a few fine, opisthocline axial riblets adapically of those spiral cords. Transition to teleoconch marked by fine line followed by start of teleoconch sculpture.

TELEOCONCH. Consisting of about $6 \frac{1}{2}$ weakly convex whorls. First teleoconch whorl with 8 spiral cords of which 2 subsutural ones weak. Second whorl with 9 such spiral cords, third whorl with 12 . An obscure secondary spiral thread, visible under magnificantion only, appearing in middle of some of those

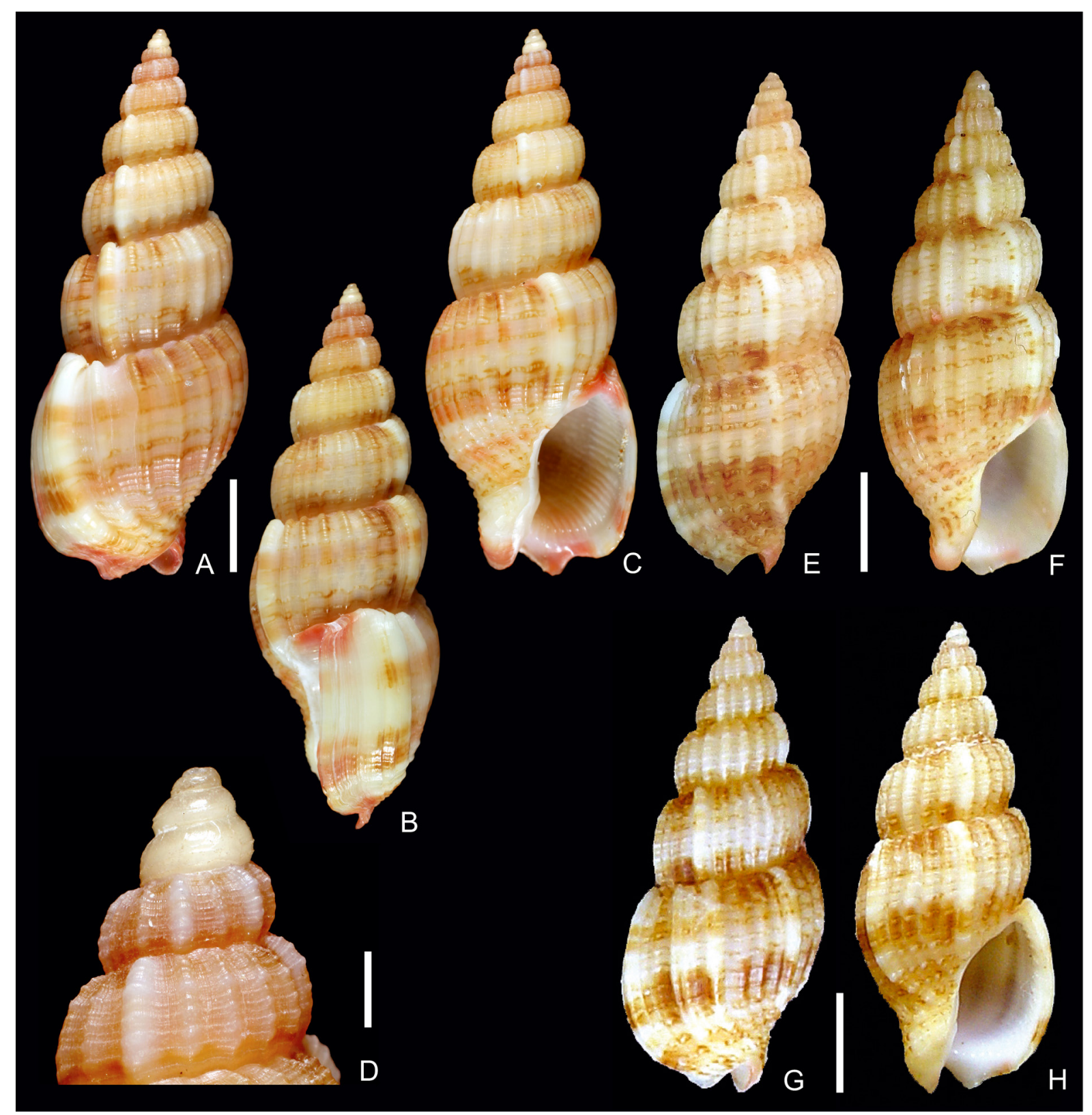

Fig. 5. Phos pulchritudus sp. nov. A-C. Holotype, S Madagascar, ATIMO VATAE stn CP3622,

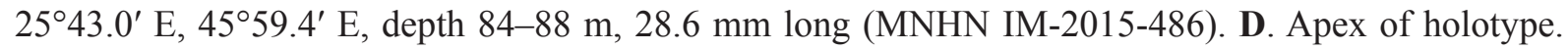
E-F. Paratype 10, S Mozambique, NE Inhaca Island, $25^{\circ} 49^{\prime} \mathrm{S}, 33^{\circ} 07^{\prime} \mathrm{E}$, dredged at 87-94 m, $25.3 \mathrm{~mm}$ long (JR). G-H. Phos cf. pulchritudus, Mozambique, off Zafora, $24 \mathrm{~mm}$ long (JR). Scale bars: A-C, $\mathrm{E}-\mathrm{H}=5.0 \mathrm{~mm} ; \mathrm{D}=0.1 \mathrm{~mm}$. 
interspaces along third whorl. Spiral cords becoming weaker along fourth whorl. Penultimate whorl with up to 20 smooth spiral cords, adapical ones alternating fine and finer, abapical ones flattened, interspaces broad. Body whorl with about 37 such spiral cords, subsutural ones fine but somewhat more accentuated when crossing axial rib; along midwhorl flat, broad or absent; along base fine; near siphonal canal more accentuated to strong. Interspaces with an unequal amount of obscure secondary spiral threads, usually 1 or 3 in interspaces along subsutural slope and base, 5 in interspaces at midwhorl. First teleoconch whorl with 13 fine but sharp axial ribs including a few slightly stronger ones, interspaces of equal size. Second whorl with 15, third whorl with 17 similar axial ribs including up to 2 varices, interspaces growing slightly broader. Penultimate whorl with 19 axial ribs, including 1 varix. Body whorl with 19 axial ribs, including 1 varix and broad prelabral varix.

APERTURE. Columella concave, gently curved, with 2 columellar folds forming a moderately sharp angulation at transition to siphonal canal, parietal denticle small. Columellar callus thin, glossy, white but bright pink around anal notch and adjacent outer lip. Outer lip with about 38 thin but moderately sharp internal lirae, extending far into aperture, adapical ones alternating fine and finer. Outer lip thick, edge blunt, with strong notch along siphonal canal, colour white but with 3 bright pink dots according to pattern at outer surface, brightest at anal notch and at notch of siphonal canal. Aperture with siphonal canal slightly more than $1 / 3$ of total shell length. Siphonal canal short, broad, open, on outside covered by fine spiral cords, colour white but with bright pink tip.

\section{Distribution and habitat}

Known from off the southern point of Madagascar in the south to Zavora (southern Mozambique) in the north (Fig. 9).

Live collected specimens were taken at between 86 and $102 \mathrm{~m}$, off Mozambique in a sponge reef area between 86 and $105 \mathrm{~m}$, ex-pisces in the stomach of 'Cachucho fish' (Polysteganus coeruleopunctatus (Klunzinger,1870)) and 'Marreco fish' (Chrysoblephus puniceus (Gilchrist \& Thompson,1908)) fished at depths between 85 and $120 \mathrm{~m}$.

\section{Remarks}

Phos pulchritudus sp. nov. is characterized by its rather slender shell with a slightly stretched base, weak sculpture and glossy surface, and the three broad darker bands and fine interrupted spiral lines; typical specimens show peculiar pink dots at the aperture and siphonal canal.

The harmonious combination of these features makes the shells of this species an outstanding piece of visual beauty.

Variability is moderately high. The shell is usually between 22 and $25 \mathrm{~mm}$ in length but occasionally up to $28.6 \mathrm{~mm}$ (holotype). Paratype 3, for example, is smaller than the holotype and differs in its lower number of teleoconch whorls $\left(5^{1 / 2}\right.$ instead of $\left.6 \frac{1}{2}\right)$. This specimen is not as slender as the holotype and on the first teleoconch whorl the abapical spiral cord (the $6^{\text {th }}$ cord) is still concealed under the suture of the subsequent whorl, while on the second whorl the same happens with the $7^{\text {th }}$ spiral cord; this is in combination with only a single fine spiral cord being present along the subsutural slope (instead of 2). This makes the number of spiral cords quite different. This specimen is also smoother than the holotype, with an obscure spiral sculpture, resulting in a number of spiral cords along the teleoconch and body whorl that is difficult to count. The internal lirae within the upper part of the outer lip (adapical) may be alternating fine and finer (see holotype) or of equal strength (paratype 1).

A number of similar looking shells, but with a white aperture including a white outer lip, lack the typical pink dots (Fig. 5G-H). It is still uncertain whether this morph is conspecific with the new species and we therefore record it tentatively as Phos cf. pulchritudus sp. nov. 
Phos idyllium (Fraussen \& Poppe, 2005) from the Philippines has a very similar sculpture and pattern, especially the pink tip of the siphonal canal. It differs, however, from P. pulchritudus sp. nov in its larger protoconch (diameter up to $1.7 \mathrm{~mm}$ ), the surface of the shell, which is even more glossy, the suture, which is accentuated (by a small notch formed where the axial sculpture suddenly stops) along the last part of the body whorl only and at the prelabral varix, the higher number of axial ribs (up to 17 on the first teleoconch whorl, 18-20 on the second and 20-25 on the penultimate and body whorls) and the usually paler protoconch.

Phos testaceus sp. nov. urn:1sid:zoobank.org:act:F00FF6BD-2E5A-484B-BC83-F7BE5F39DFF6

Figs 6, 9

\section{Etymology}

The specific epithet of Phos testaceus sp. nov. is derived from the Latin adjective 'testaceus', meaning 'of baked earth' or 'pottery', which refers to the pale brownish colour.

\section{Material examined}

Holotype

MADAGASCAR • lv (24.0 mm long); Leven Banc, MIRIKY stn DW3213; 12 $31^{\prime} \mathrm{S}, 47^{\circ} 52^{\prime} \mathrm{E}$; depth 262-269 m; Jun. 2009; MIRIKY exped.; MNHN IM-2013-36722 (Figs 6A-D, 9).

\section{Paratypes}

MADAGASCAR - 1 lv; same collection data as for holotype; paratype 1; MNHN IM-2013-36981 -

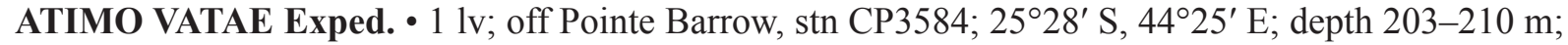
May 2010; ATIMO VATAE exped.; paratype 2; MNHN IM-2000-35090 (Fig. 6E-F) • 1 dd; same collection data as for preceding; paratype 3; MNHN IM-2000-35091 • $1 \mathrm{dd}$; same collection data as for preceding; paratype 4; KF $7864 \bullet 1 \mathrm{dd}$; same collection data as for preceding; paratype 5; JR • 1 lv; near Manantenna, stn DW3528; 2424' S, 473' E; depth 424-436 m; May 2010; ATIMO VATAE exped.; paratype 6; MNHN IM-2000-35093.

\section{Other material}

MADAGASCAR • 1 dd; Campagne CREVETTIERE 1971 stn CH13; 1241' S, 48 ${ }^{\circ} 16^{\prime}$ E; depth $308-$ 314 m; 1974; Campagne CREVETTIERE exped.; MNHN. - MIRIKY Exped. • 2 lv; Leven Banc, stn DW3213; 12³1' S, 4752' E; depth 262-269 m; Jun. 2009; MIRIKY exped.; MNHN • 1 dd; between Nosy Bé and Leven Banc, stn DW3214; 12 ${ }^{\circ} 33^{\prime}$ S, 47 $7^{\circ} 2^{\prime}$ E; depth 302-327 m; Jun. 2009; MIRIKY

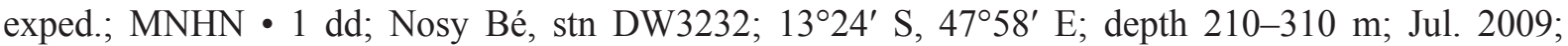
MIRIKY exped.; MNHN. - ATIMO VATAE Exped. • 1 lv, 1 dd (jv); near Manantenna, stn DW3528; 242ㄴ $\mathrm{S}, 4^{\circ} 33^{\prime}$ E; depth 424-436 m; May 2010; ATIMO VATAE exped.; MNHN • 2 dd; stn DW3529; 242ㄴ' S, 47³3' E; depth 402-407 m; May 2010; ATIMO VATAE exped.; MNHN • 5 dd; off Pointe

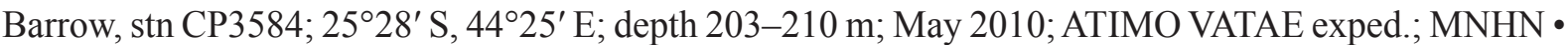

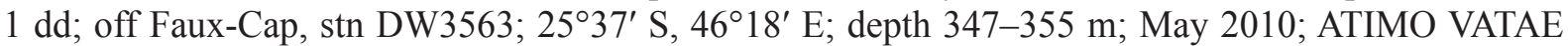

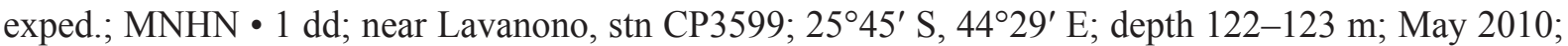
ATIMO VATAE exped.; MNHN.

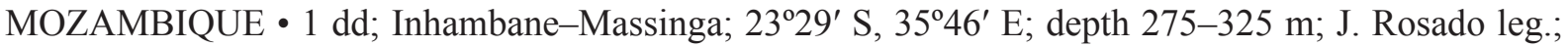
JR (Fig. 6G-H).

\section{Description (holotype)}

General. Shell of medium size, $24 \mathrm{~mm}$ in length, thin but solid. Shape fusiform with high spire; whorls rather convex, with weak shoulder; base stretched. Axial sculpture dominant (Fig. 6A-D). Colour pale brown, alternating with white to greyish-white spiral band along upper spire whorl and along base. 
Primary spiral cords usually brown coloured, slightly darker on axial ribs. Upper half of whorls with a single broad, brown spiral band, subsuturally usually paler. This broad band usually darker when crossing axial ribs. Body whorl with 3 brown to dark brown spiral bands. Siphonal canal paler.

Protoconch (Fig. 6D). Multispiral, tip chipped, consisting of about $3 \frac{1}{2}$ whorls by estimation, $1 \mathrm{~mm}$ high, diameter $1.2 \mathrm{~mm}$; colour white, greyish to yellowish with spiral cords of same colour. First remaining whorl well convex, smooth, glossy; from $2^{\text {nd }}$ whorl on with 2 spiral cords; spiral cords gradually more

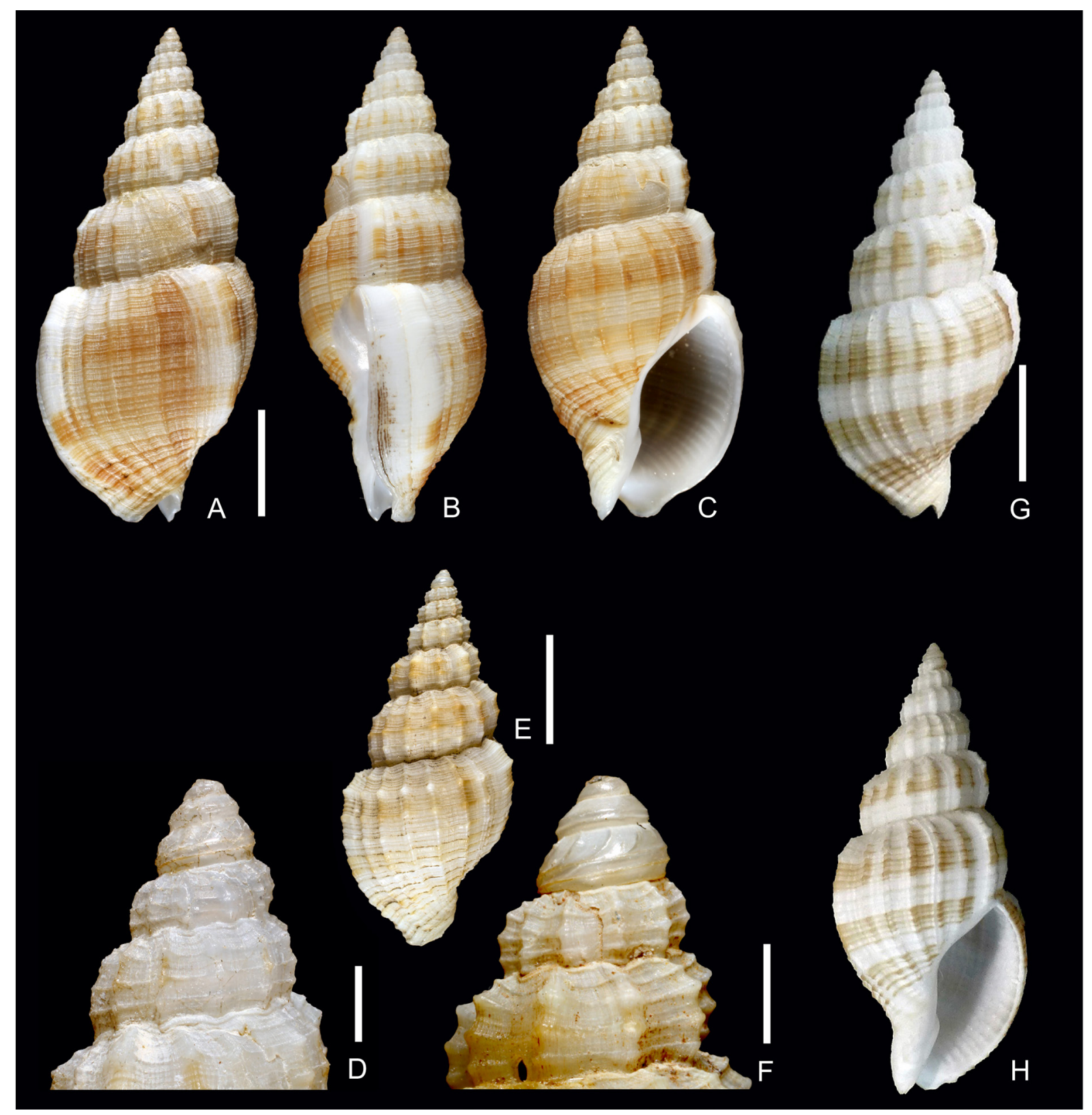

Fig. 6. Phos testaceus sp. nov. A-C. Holotype, Madagascar, Leven Banc, MIRIKY stn DW3213, $12^{\circ} 31^{\prime} \mathrm{S}, 47^{\circ} 52^{\prime} \mathrm{E}$, depth 262-269 m, $24.0 \mathrm{~mm}$ long (MNHN IM-2013-36722). D. Apex of holotype. E. Paratype 2, Madagascar, off Pointe Barrow, ATIMO VATAE stn CP3584, $25^{\circ} 28^{\prime} \mathrm{S}, 44^{\circ} 25^{\prime} \mathrm{E}$, depth 203-210 m (MNHN IM-2000-35090). F. Apex of paratype 2. G-H. Dead-collected specimen from

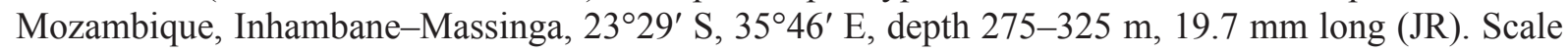
bars: A-C, E, G-H = $5.0 \mathrm{~mm}$; D, F = $1.0 \mathrm{~mm}$. 
abapically situated; last half whorl with a few strongly opisthocline axial riblets adapically of spiral cords. Transition to teleoconch distinct, marked by strongly opisthocline axial line and start of teleoconch sculpture.

TELEOConch. Consists of 7 weakly convex whorls, laterally slightly flattened, with weak angulation below subsutural slope. First teleoconch whorl with 3 primary spiral cords, interspaces broad with 1 fine secondary spiral thread. A fine spiral thread appearing in subsutural interspace along second teleoconch whorl. Third teleoconch whorl with 3 primary spiral cords, interspaces broad, with 1 (adapical interspaces) to 3 (abapical interspaces) fine secondary spiral threads of which middle secondary spiral cords slightly stronger. Penultimate whorl with 25 spiral cords of unequal strength, interspaces broad. Body whorl with 60 such spiral cords, each fine primary spiral cord usually alternating with 3 fine secondary spiral cords, at base stronger with narrower interspaces. First teleoconch whorl with 10 fine but sharp axial ribs including 1 slightly stronger varix-like one, interspaces broad. Second whorl with 11 such axial ribs. Axial ribs growing slightly stronger, their number increasing. Penultimate whorl with 18 axial ribs, including 2 varices. Body whorl with 19 axial ribs, including 1 varix and broad prelabral varix. Fine but rather sharp, microscopic incremental lines visible in between spiral sculpture.

APERTURE. Columella concave, gently curved towards a straight parietal part, with 2 columellar folds forming a moderately sharp angulation at transition to siphonal canal, occasionally with a minute parietal denticle. Callus thin, white, glossy, forming border callus at transition to outer lip. Outer lip with 21 thin but moderately sharp internal lirae, extending far into aperture; at least 4 adapical ones with minute denticle inside outer lip. Outer lip thick, edge sharp, with weak notch along siphonal canal. Aperture with siphonal canal about $2 / 5$ of total shell length. Siphonal canal short, broad, open, on outside covered by broad but flattened spiral cords.

\section{Distribution}

Known from Madagascar and Mozambique (Fig. 9).

\section{Remarks}

Phos testaceus sp. nov. is characterized by its moderately broad shape, with a slightly stretched base, and the fine axial and spiral sculpture, in combination with a rather pale colour.

Phos geminus sp. nov. differs from P. testaceus sp. nov. in its slender shape with a higher spire and smaller aperture, the laterally flattened whorls, the larger axial ribs that are fewer in number, the larger spiral cords, the strongly twisted siphonal canal covered by a cancellate sculpture and the more colourful shell.

\section{Phos sp.}

Fig. 7

\section{Material examined}

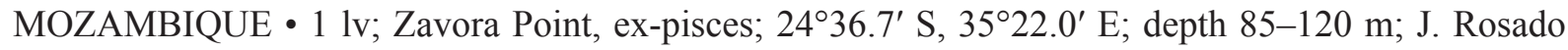
leg.; JR (Fig. 7A-B).

SOUTH AFRICA • 1 dd; north Transkei, Msikaba; depth 90-120 m; 2004; F. Lorenz leg.; dredge; KF 4691(Fig. 7C-D).

\section{Distribution and habitat}

This form is known from Transkei (northeastern South Africa) in the south to Zavora (southern Mozambique) in the north. Its bathymetric range is between 90 and $120 \mathrm{~m}$ (the single live-collected specimen in South Africa). It was also found ex-pisces, in the stomach of 'Cachucho fish' (Polysteganus 
coeruleopunctatus (Klunzinger,1870)) or 'Marreco fish' (Chrysoblephus puniceus (Gilchrist \& Thompson, 1908)), caught at between 90 and $145 \mathrm{~m}$.

\section{Remarks}

This species is characterized by its glossy shell with obscure spiral sculpturing in combination with dark spiral bands and fine, interrupted but well-defined spiral lines. The harmonious combination of these features makes this shell an outstanding piece of visual beauty that recalls some species belonging to the genus Lyria Gray, 1847 (Volutidae).

Phos pulchritudus sp. nov. looks quite similar in pattern and gloss but differs from this species in its slender shape with a stretched base, the deeper suture, the presence of a notch at the transition from the outer lip to the siphonal canal, the higher number of axial ribs, the higher number of spiral cords, the fine spiral lines in the pattern that form specks (rather than well defined short lines), and by the lack of pink spots at the outer lip of the aperture and siphonal canal.

Both Phos laevis Kuroda \& Habe, 1961 from the West Pacific and P. scitamentus Fraussen \& Poppe, 2005 from the Philippines have a similar gloss but differ from this species in their larger number of axial ribs, the uniform colour without pattern and the smaller adult size.

\section{Discussion}

The present paper expands the range of four species of Phos and describes five species as new to science. Based on the data presented in this paper we estimate that almost half of the biodiversity of Photinae in Mozambique and Madagascar is endemic. The introdution of an integrative approach for taxonomic purposes, including the use of molecular data, may increase this estimation. Our results support the hypothesis of a high rate of endemism in the western Indian Ocean (sensu Spalding et al. 2007). This paper also demonstrates the importance of biodiversity exploration towards the deep sea, where half of the species of Phos discussed in this paper are new to science.

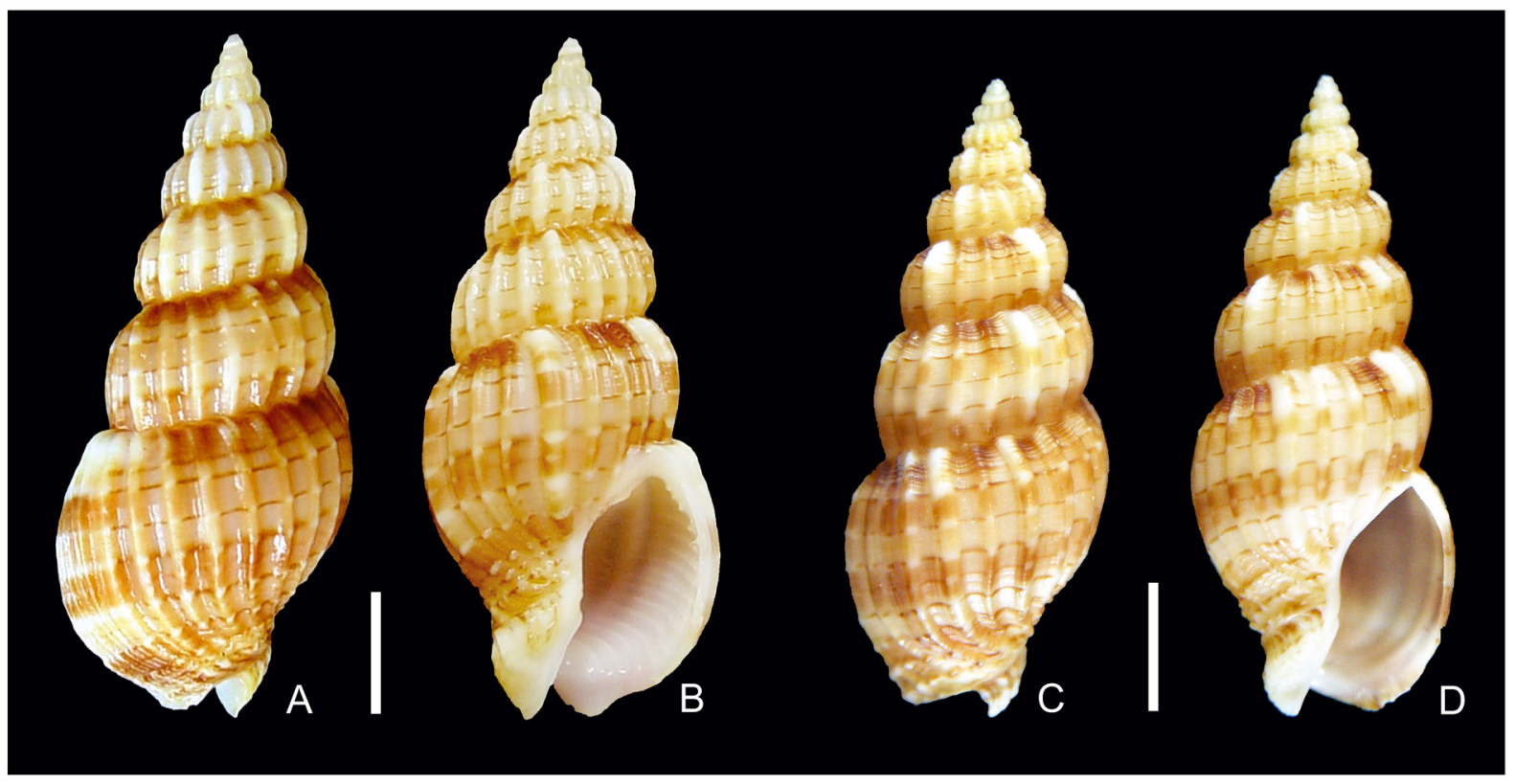

Fig. 7. Phos sp. A-B. Specimen from Southern Mozambique, Zavora Point, $24^{\circ} 36.7^{\prime} \mathrm{S}, 35^{\circ} 22.0^{\prime} \mathrm{E}$, ex-pisces, depth 85-120 m, $26.6 \mathrm{~mm}$ long (JR). C-D. Specimen from South Africa, north Transkei, Msikaba, dredged at 90-120 m, $24.5 \mathrm{~mm}$ long (KF 4691). Scale bars: $5.0 \mathrm{~mm}$. 


\section{Acknowledgements}

We thank Virginie Héros (MNHN) and Philippe Bouchet (MNHN) for allowing us to work on the MNHN material, Manuel Caballer Gutierrez (MNHN project E-RECOLNAT: ANR-11-INBS-0004) and Philippe Maestrati (MNHN) for photography, Barbara Buge (MNHN) for managing the specimens from the Barcode Collection, Gilberto Marani (MNHN) for producing the maps, and Felix Lorenz (Germany),

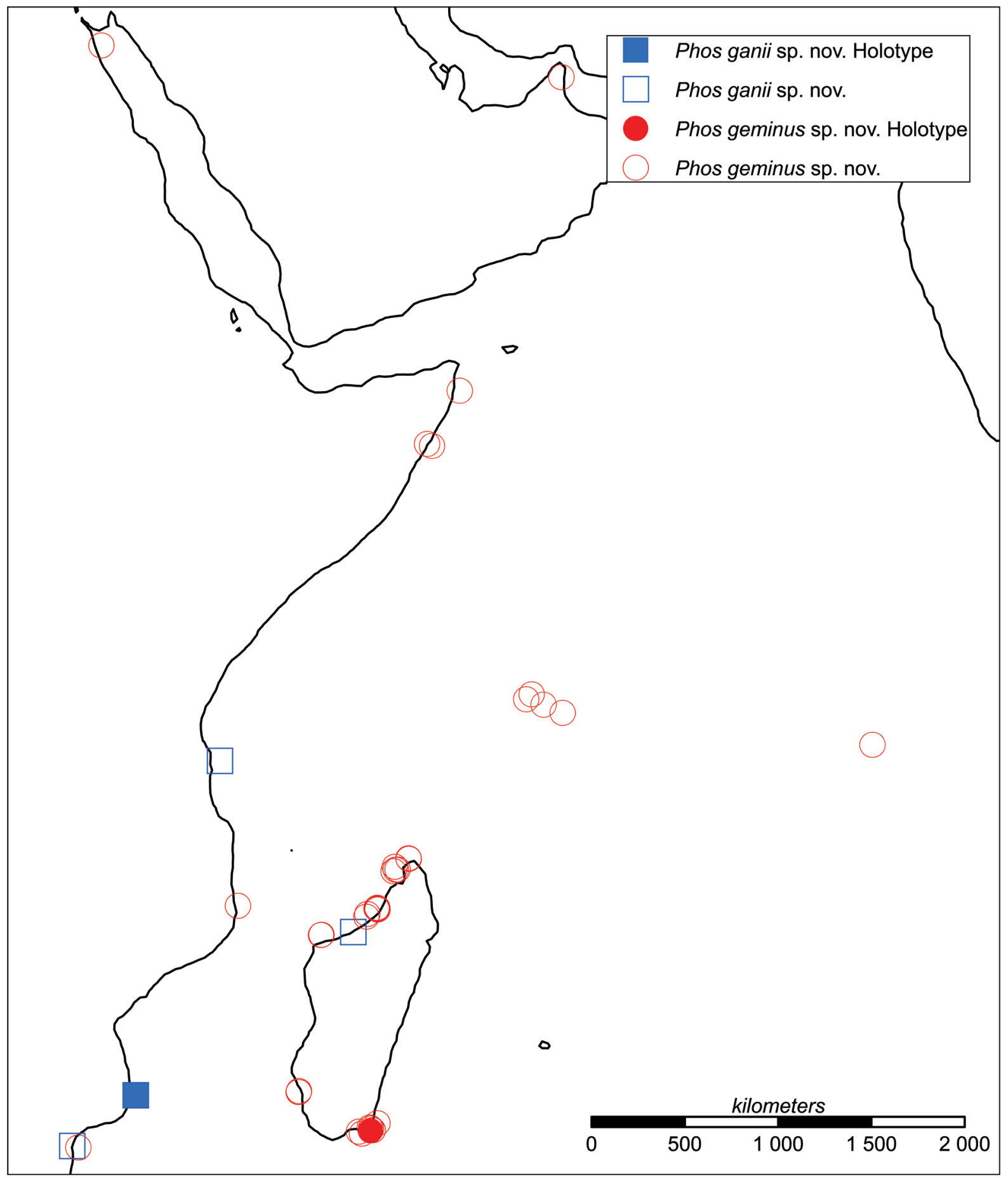

Fig. 8. Distribution of Phos ganii sp. nov. and P. geminus sp. nov. 
Guido Poppe (Belgium, Philippines), Alan Seccoumbe (South Africa) and Peter Stahlschmidt (Germany) for making additional material available for study.

This research received support from the SYNTHESYS Project (http://www.synthesys.info/), which is financed by the European Community Research Infrastructure Action under the FP7 'Capacities' Program.

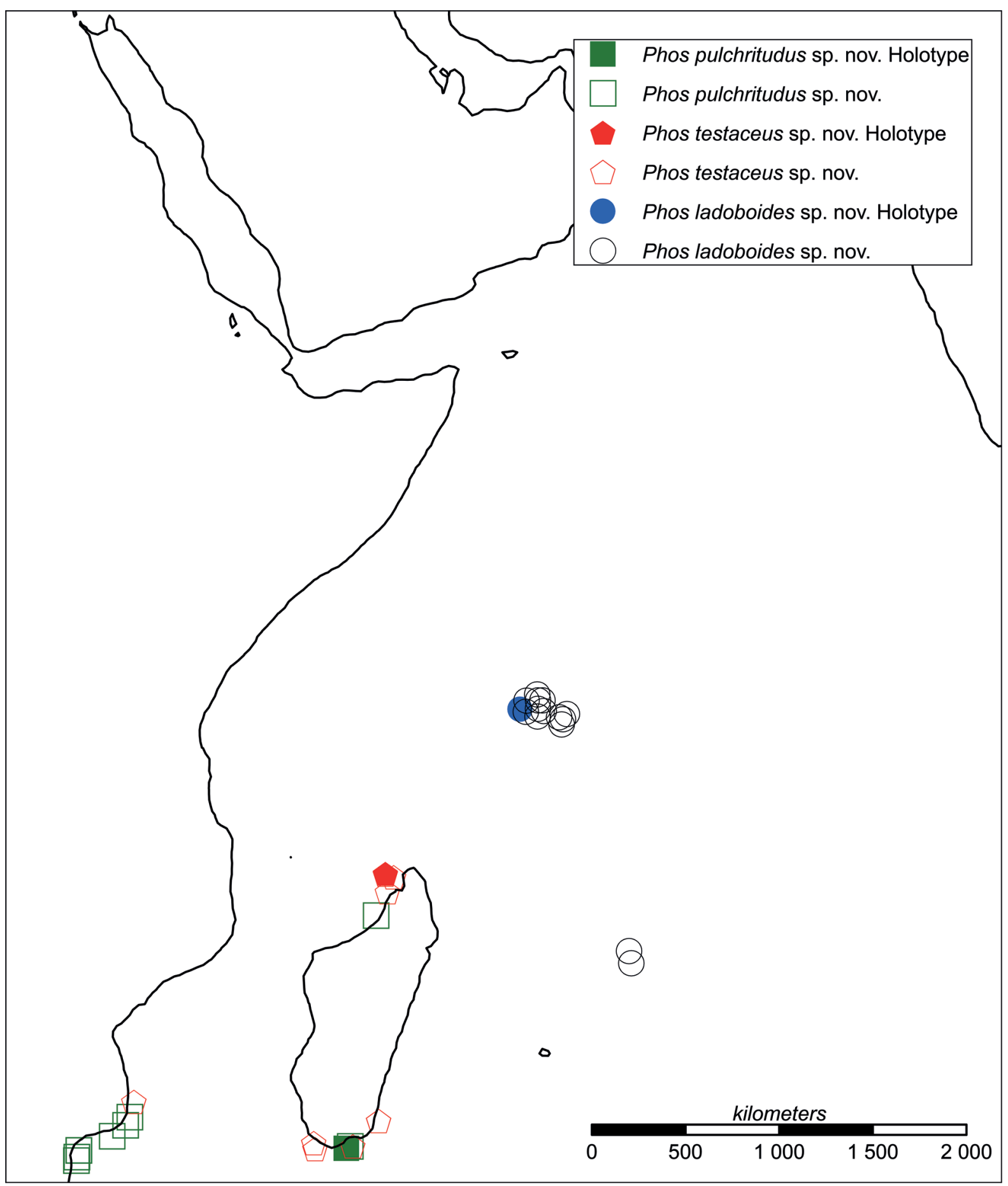

Fig. 9. Distribution of Phos ladoboides sp. nov., P. pulchritudus sp. nov. and P. testaceus sp. nov. 


\section{References}

Bouchet P., Héros V., Lozouet P. \& Maestrati P. 2008. A quarter- century of deep-sea malacological exploration in the South and West Pacific: where do we stand? How far to go? In: Héros V., Cowie R.H. \& Bouchet P. (eds) Tropical Deep-Sea Benthos 25: 9-40. Mémoires du Muséum national d'Histoire naturelle 196, Muséum national d'histoire naturelle, Paris.

Fraussen K. \& Poppe G.T. 2005. Revision of Phos and Antillophos (Buccinidae) from the central Philippines. Visaya 1 (5): 76-115.

Galindo L.A., Puillandre N., Utge J., Lozouet P. \& Bouchet P. 2016. The phylogeny and systematics of the Nassariidae revisited (Gastropoda, Buccinoidea). Molecular Phylogenetics and Evolution 99: 337-353. https://doi.org/10.1016/j.ympev.2016.03.019

Habe T. 1961. Coloured Illustrations of the Shells of Japan (II). Hoikusha, Osaka. [In Japanese.]

Hayashi S. \& Habe T. 1965. Descriptions of four new gastropodous species from Enshunanda, Honshu. Venus 24 (1): 10-15.

Kilburn R.N. 2000. Description of new species of Phos and Nassarius from south-eastern Africa (Mollusca: Gastropoda: Buccinidae, Nassariidae). Annals of the Natal Museum 41: 203-208.

Kilburn R.N., Marais J.P. \& Fraussen K. 2010. Buccinidae. In: Marais A.P. \& Seccoumbe A.D. (eds) Identification Guide to the Seashells of South Africa: 16-52. Centre for Molluscan Studies, Groenkloof, South Africa.

Montfort D. de. 1810. Conchyliologie systématique, et Classification méthodique des Coquilles; offrant leurs Figures, leur Arrangement générique, leurs Descriptions caractéristiques, leurs Noms; ainsi que leur Synonymie en plusieurs Langues. Coquilles univalves, non cloisonnées. Vol. 2. F. Schœll, Paris. Available from https://www.biodiversitylibrary.org/page/11065017 [accessed 15 Sep. 2020].

Sowerby G.B. III. 1913. Descriptions of eight new marine Gastropoda, mostly from Japan. The Annals and Magazine of Natural History, Series 811 (66): 557-560. https://doi.org/10.1080/00222931308693356

Spalding M.D., Fox H.E., Allen G.R., Davidson N., Ferdana Z.A., Finlayson M., Halpern B.S., Jorge M.A., Lombana A., Lourie S.A., Martin K.D., McManus E., Molnar J., Recchia C.A. \& Robertson J. 2007. Marine ecoregions of the world: a bioregionalization of coastal and shelf areas. Bioscience 57 (7): 573-582. https://doi.org/10.1641/B570707

Terryn Y. 2018. Terebrid (Gastropoda: Conoidea) attachments of Xenophora pallidula (Reeve, 1842). Neptunea 14 (4): 1-5.

Verduin A. 1977. On a remarkable dimorphism of the apices in many groups of sympatric, closely related marine gastropod species. Basteria 41: 91-95.

Manuscript received: 4 May 2020

Manuscript accepted: 29 July 2020

Published on: 16 October 2020

Topic editors: Rudy Jocqué

Section editor: Thierry Backeljau

Desk editor: Danny Eibye-Jacobsen

Printed versions of all papers are also deposited in the libraries of the institutes that are members of the EJT consortium: Muséum national d'histoire naturelle, Paris, France; Meise Botanic Garden, Belgium; Royal Museum for Central Africa, Tervuren, Belgium; Royal Belgian Institute of Natural Sciences, Brussels, Belgium; Natural History Museum of Denmark, Copenhagen, Denmark; Naturalis Biodiversity Center, Leiden, the Netherlands; Museo Nacional de Ciencias Naturales-CSIC, Madrid, Spain; Real Jardín Botánico de Madrid CSIC, Spain; Zoological Research Museum Alexander Koenig, Bonn, Germany; National Museum, Prague, Czech Republic. 